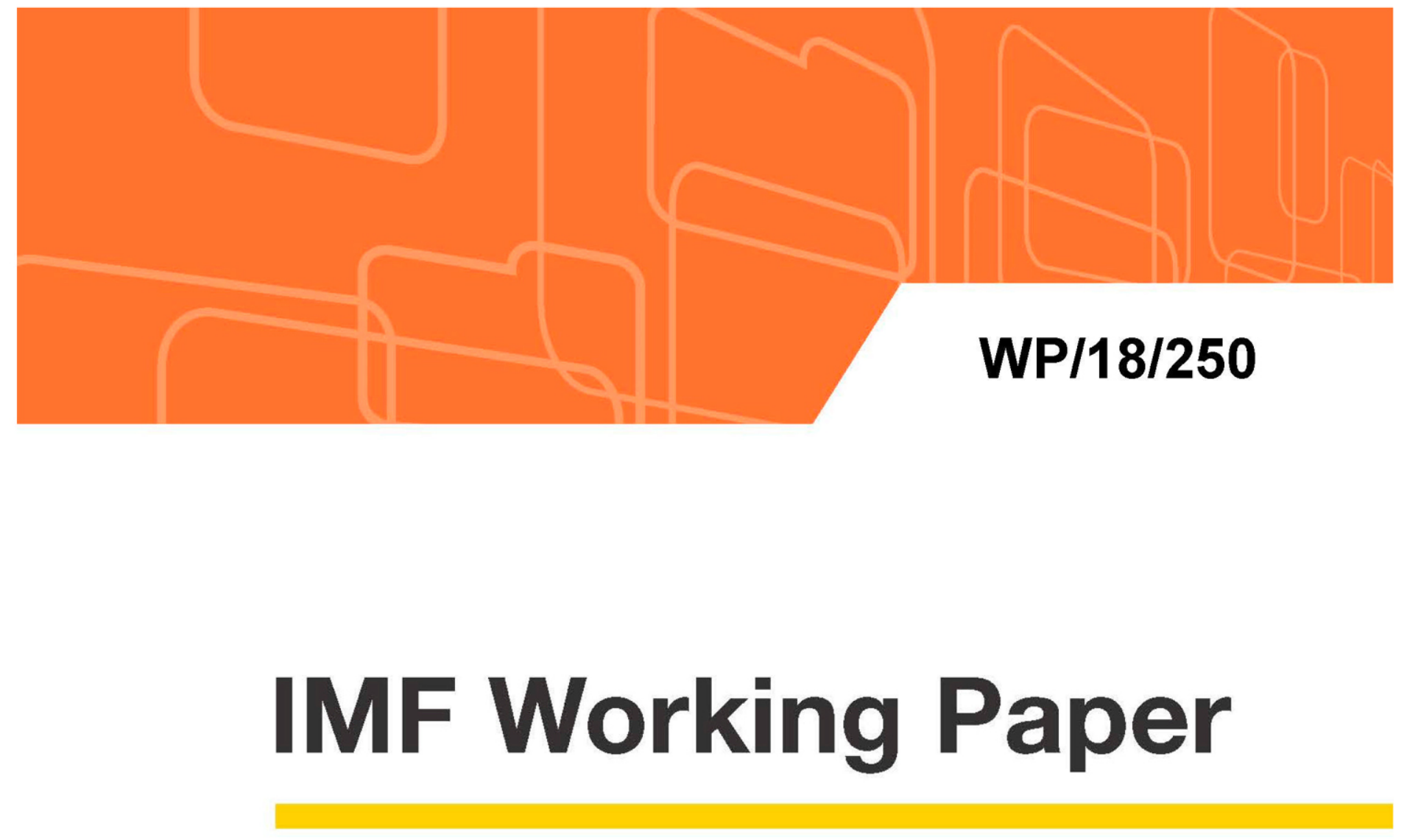

\title{
House Price Synchronicity, Banking Integration, and Global Financial Conditions
}

\author{
by Adrian Alter, Jane Dokko, Dulani Seneviratne
}

IMF Working Papers describe research in progress by the author(s) and are published to elicit comments and to encourage debate. The views expressed in IMF Working Papers are those of the author(s) and do not necessarily represent the views of the IMF, its Executive Board, or IMF management. 


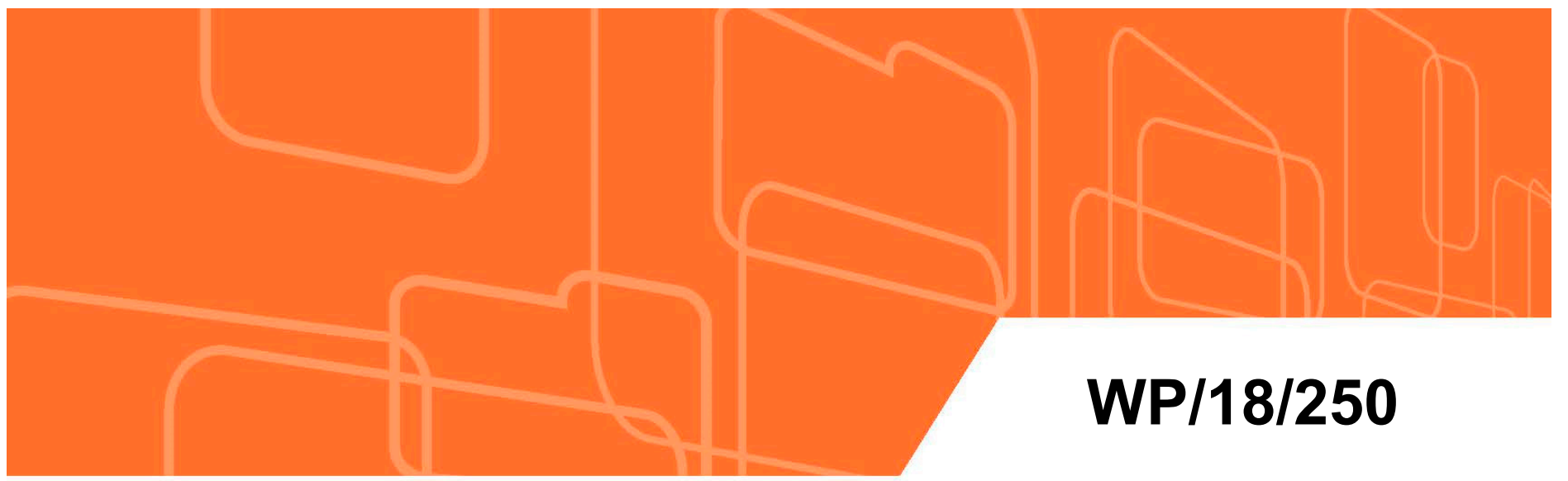

\section{IMF Working Paper}

\section{House Price Synchronicity, Banking Integration, and Global Financial Conditions}

by Adrian Alter, Jane Dokko, Dulani Seneviratne

IMF Working Papers describe research in progress by the author(s) and are published to elicit comments and to encourage debate. The views expressed in IMF Working Papers are those of the author(s) and do not necessarily represent the views of the IMF, its Executive Board, or IMF management. 


\title{
IMF Working Paper
}

Monetary and Capital Markets Department

\section{House Price Synchronicity, Banking Integration, and Global Financial Conditions \\ Prepared by Adrian Alter, Jane Dokko, Dulani Seneviratne ${ }^{1}$}

Authorized for distribution by Claudio Raddatz

November 2018

\section{IMF Working Papers describe research in progress by the author(s) and are published to elicit comments and to encourage debate. The views expressed in IMF Working Papers are those of the author(s) and do not necessarily represent the views of the IMF, its Executive Board, or IMF management.}

\begin{abstract}
We examine the relationship between house price synchronicity and global financial conditions across 40 countries and about 70 cities over the past three decades. The role played by cross-border banking flows in residential property markets is examined as well. Looser global financial conditions are associated with greater house price synchronicity, even after controlling for bilateral financial integration. Moreover, we find that synchronicity across major cities may differ from that of their respective countries', perhaps due to the influence of global investors on local house price dynamics. Policy choices such as macroprudential tools and exchange rate flexibility appear to be relevant for mitigating the sensitivity of domestic housing markets to the rest of the world.

JEL Classification Numbers: E30, F42, F44

Keywords: Housing market; global liquidity; financial conditions; banking intergration; business cycles

Author’s E-Mail Address: AAlter@imf.org; Jane.Dokko@chi.frb.org; DSeneviratne@imf.org

\footnotetext{
${ }^{1}$ This paper is background to a subsection of analyses presented in Chapter 3 of the April 2018 GFSR, "House Price Synchronization: What Role for Financial Factors?" (IMF 2018a). We would like to thank Tobias Adrian, Alan Feng, Mitsuru Katagiri, Romain Lafarguette, and Claudio Raddatz, for helpful comments, suggestions, and guidance. All Executive Board, IMF management, the Federal Reserve Bank of Chicago, or the Federal Reserve Board.
} remaining errors are our own. The views expressed in this paper do not necessarily represent the views of the IMF, its
\end{abstract}


ABSTRACT

I. INTRODUCTION

II. DATA AND MEASUREMENT

A. House Price Gap Synchronicity

B. Business Cycle Synchronicity

C. Bilateral Banking Integration

D. Global Financial Conditions

E. Other Controls

III. COUNTRY-LEVEL ANALYSIS

A. Empirical Strategy

B. Results

C. Robustness Checks

IV. CITY-LEVEL ANALYSIS

A. Network Analysis: House Price Interconnectedness at City Level

B. Empirical Strategy

C. Results

V. EXTENSIONS: THE IMPACT OF MACROPRUDENTIAL POLICIES

A. Empirical Strategy

B. Results

\section{FIGURES}

1. House Price Gap Synchronicity Across Countries and Cities

2. House Price Synchronicity and Transmission of External Shocks

3. Impact of Global Financial Conditions on House Price Synchronization

4. House Price Interconnectedness Among Countries vs. Cities

5. Average House Price Growth and Demand-side Macroprudential Policies

6. Impact of Macroprudential Measures on House Price Synchronicity

$\underline{24}$

TABLES

1. House Price Gap Synchronicity at Country Level and Global Factors

2. House Price Gap Synchronicity at Country Level and Global Factors-Robustness

Checks: Global Factors $\underline{16}$

3. House Price Gap Synchronicity at Country Level and Global Factors-Robustness Checks: Additional Controls

4. House Price Gap Synchronicity at Country Level and Global Factors-Robustness Checks: Clustering of Standard Errors 
5. House Price Gap Synchronicity at City Level and Global Factors-Two-Way

Clustering $\underline{21}$

6. House Price Gap Synchronicity at City Level and Global Factors-Multi-Way Clustering $\underline{22}$

\section{ANNEXES}

I. Data Sources, Coverage, and Summary Statistics $\underline{31}$

II. Alternative Measures of House Price Synchronicity $\underline{35}$

III. Methodology-House Price Interconnectedness Analysis $\underline{40}$

IV. Impact of Macroprudential Measures on House Price Synchronicity-Regression

Results

41




\section{INTRODUCTION}

As global liquidity surged owing to accommodative financial conditions, house prices across advanced and emerging market economies have experienced greater synchronicity. IMF (2018a) finds that nearly 80 percent of countries and cities within a broad set of developed economies have experienced positive house price growth rates in the past decade, while this figure is over 60 percent for emerging market economies and cities. Moreover, over time, median synchronicity in house price gaps - measured by extracting the cyclical component of real house prices - has steadily increased over time across countries and cities (Figure 1). ${ }^{2}$

House price synchronicity is of particular interest given that greater comovement in house prices could amplify the propagation of external shocks. These shocks could be directly transmitted to the domestic economy through channels such as portfolio, balance sheet, and liquidity, or indirectly through risk premium and confidence channels (Allen and Gale 2000; Longstaff 2010). Simultaneous changes in mortgage rates due to global financial conditions could lead to greater house price synchronicity, thus propagating shocks to aggregate demand when financial conditions tighten sharply. At the same time, an increase in global demand for safe assets may compress sovereign spreads where risk is perceived to be low, thereby pushing down mortgage rates and supporting house price booms in those countries (Bernanke et al. 2011). For instance, foreign capital may be a driver of residential property markets in global cities such as London, New York, or Tokyo, especially during "flight to safety" episodes (Badarinza and Ramadorai 2018). In addition, as illustrated in Figure 2, asset managers may rebalance their portfolios to mitigate their losses, thus resulting in dwindling equity price returns (i.e., portfolio channel); this impact could be further amplified due to asset classes such as REITS. In addition, an exogenous shock to house prices may lead to asset fire sales and deleveraging that would result in declining collateral values and hindering the availability of credit in the economy (i.e., bank balance sheet channel). An exogenous shock could also heighten the rollover risk as investors suffering losses may find it difficult to obtain further financing opportunities, thereby affecting the aggregate demand (i.e., liquidity channel). A shock to the financial system in one country could also result in elevated risk premia in other countries, therefore affecting the aggregate demand through indirect channels (i.e., risk premium/confidence channel).

Even though housing is a non-tradable asset, Claessens et al. (2011a) — echoing past research such as Terrones (2004) — points out the presence of high synchronicity in their sample of countries, partially reflecting the importance of global factors such as global interest rates,

\footnotetext{
${ }^{2}$ See IMF (2018a) for a detailed discussion on trends in house prices across countries and cities. House price synchronicity measures are presented in detail in section II and Annex II.
} 
U.S. business cycles, and global commodity prices. In the same spirit, Hirata et al. (2012) allude to the role of global integration of housing markets across advanced and emerging market economies as a determinant of house price synchronicity. ${ }^{3}$

Nevertheless, house price synchronicity may also be reflective of the co-movement in economic cycles (in other words, due to business cycle synchronicity). Claessens et al (2011b) notes that business cycles are highly synchronized with house price cycles. Indeed, past research has identified bilateral financial and trade linkages as two possible determinants of business cycle synchronicity between countries (IMF 2013; Kalemli-Ozcan et al. 2013a, 2013b; Duval et al 2016).

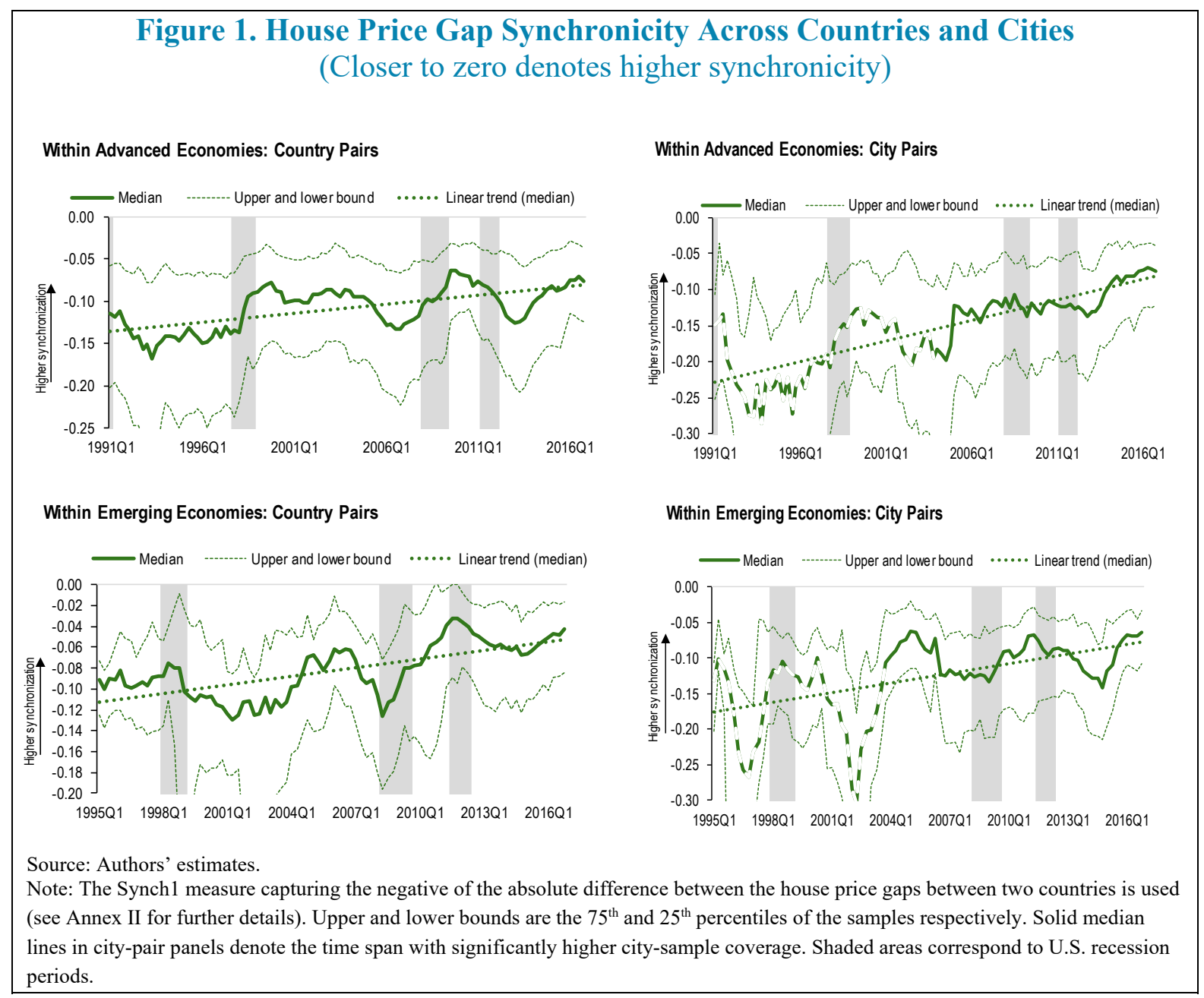

\footnotetext{
${ }^{3}$ Several papers focus on house price co-movement within a country. For instance, Landier, Sraer, and Thesmar (2017) find evidence for increased correlation of U.S. housing market across states owing to the rise of large banks.
} 
In this paper, building upon the literature on global financial conditions and house prices, we analyze the role of bilateral financial linkages and global financial conditions above-and-beyond that of business cycle synchronicity as a driver of house price synchronicity. We perform bilateral panel data analyses at country-pair level with nearly 50,000 observations and at major city-pair level with nearly 70,000 observations for a broader set of advanced and emerging economies (over 40 economies) and cities (over 70 cities) than previously analyzed. In particular, we aim to address the following questions: (1) Do global financial conditions amplify the house price synchronicity controlling for bilateral macro-financial linkages? (2) Is there an association between bilateral bank linkages and house price synchronicity above-and-beyond that of business cycle synchronicity? (3) What is the role of various institutional factors in either mitigating or amplifying the impact of global financial conditions on house price synchronicity? (4) Do policy tools such as macroprudential policies still turn out to be effective in addressing domestic vulnerabilities in the presence of heightened house price synchronicity?

Our main findings are fourfold. First, the importance of global factors in house price synchronicity as documented in past research still holds when a broader sample of countries and cities with coverage spanning through end-2016 is used. Notably, we find that abundant global liquidity as well as loose financial conditions (in addition to other global factors such as global interest rates) are positively associated with house price synchronicity across country-pairs as well as across major city-pairs. Thus, this paper sheds light on the important

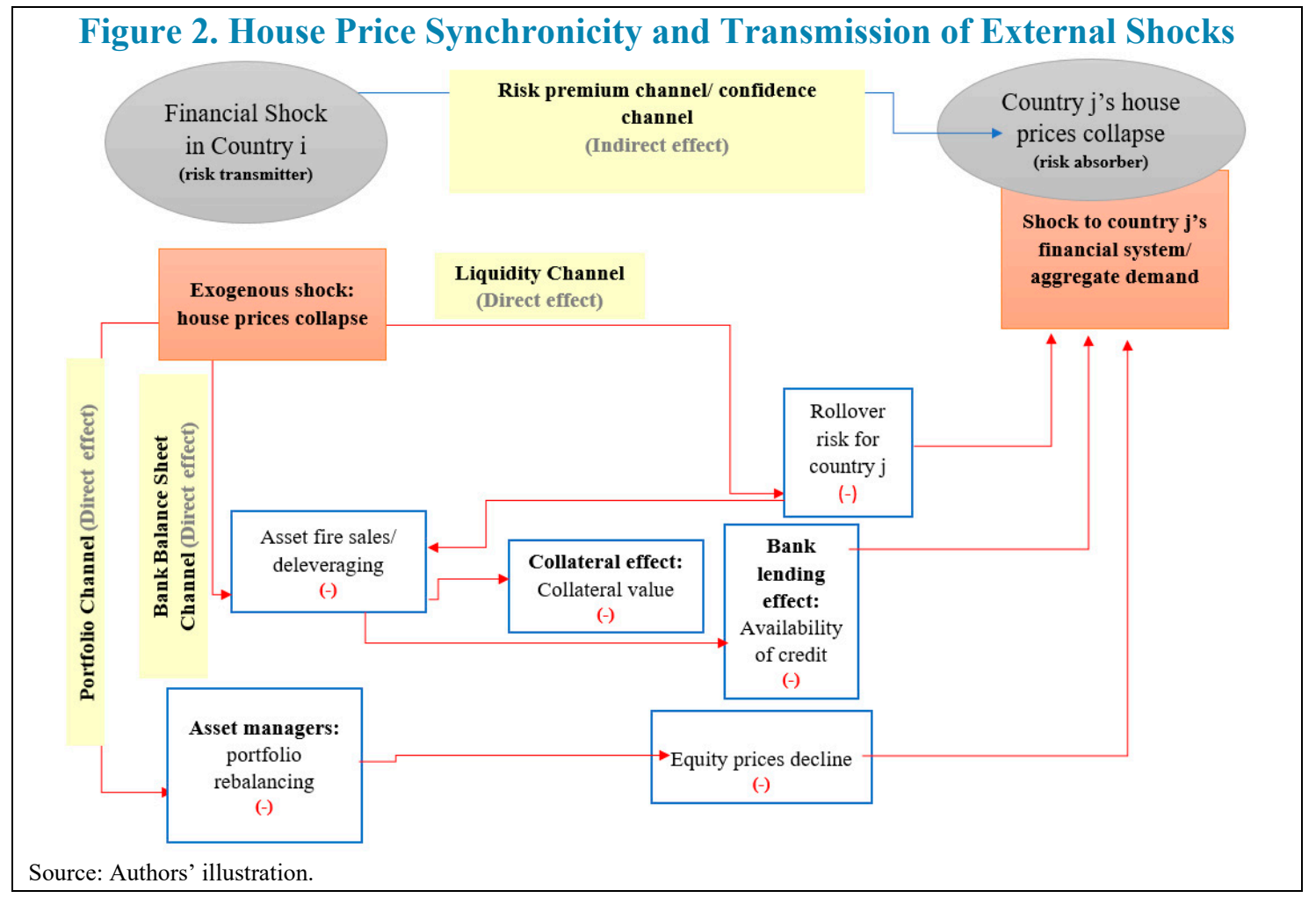


role played by mounting financial integration on housing markets across the globe. Second, we find that greater exchange rate flexibility attenuates the positive impact of global factors on house price synchronicity. Third, bilateral relationships such as past co-movement in business cycles and bilateral bank linkages are also positively associated with house price synchronicity. Finally, we find that the macroprudential policies aimed at tackling domestic vulnerabilities may have the additional impact of reducing countries' house price synchronicity with the rest of the region and the world.

The rest of the paper is structured as follows. Section II describes the data and the construction of the main indicators used in the empirical analyses. Section III presents the main country-level empirical analysis and additional robustness checks. Section IV presents the city-level analysis where we first provide a network analysis on city-level interconnectedness dynamics followed by the empirical analysis. Section V extends the analysis further, looking at the impact of macroprudential policies on house price synchronicity. Section VI concludes.

\section{Data And Measurement}

This section presents a brief description of the construction of the main variables used in our regression analyses. Further information on underlying data sources, descriptions, and the economies and cities covered in this paper are presented in Annex I.

\section{A. House Price Gap Synchronicity}

We employ a measure of house price synchronicity that can be computed at any point in time (in other words at time-series level) rather than as period-wise computations; this measure also provides the additional advantage of not being bound between -1 and 1 .

Synchronicity is calculated using the instantaneous quasi-correlation, originally presented by Morgan, Rime, and Strahan (2004) and used in recent business cycle literature (such as Duval et al. 2016; IMF 2013; Kalemli-Ozcan et al. 2013a, 2013b). ${ }^{4}$ House price synchronicity $\left(\right.$ HPsynch $_{i j t}$ ) between country $i$ and $j$ at time $t$ is measured as follows:

$$
H_{P S y n c h}{ }_{i j t}=\frac{\left(\text { HPgap }_{i t}-\overline{\operatorname{HPgap}_{\imath}}\right)\left(\operatorname{HPgap}_{j t}-\overline{\mathrm{HPgap}_{J}}\right)}{\sigma_{i}^{g a p} \sigma_{j}^{g a p}},
$$

where $\mathrm{HPgap}_{i t}$ and $\mathrm{HPgap}_{j t}$ stand for house price gap of country i and j respectively at quarter $t$ and the gaps are measured as explained above. $\overline{\operatorname{HPgap}_{\iota}}$ and $\overline{\operatorname{HPgap}_{\mathrm{J}}}$ are the

\footnotetext{
${ }^{4}$ For robustness purposes, alternative measures of house price synchronicity are considered in Annex II.
} 
average house price gaps of countries $i$ and $j$ respectively, while $\sigma_{i}^{g a p}, \sigma_{j}^{g a p}$ are the standard deviations of house piece gaps of countries $i$ and $j$ respectively.

House price gaps are measured by extracting the cyclical component of real house prices using the band-pass filter of Christiano and Fitzgerald (2003), with the maximum length of 30 years to capture medium-term financial cycles ${ }^{5}$. The above cyclical components of house prices are then taken as a ratio of the house price levels to obtain house price gaps ${ }^{6}$.

\section{B. Business Cycle Synchronicity}

Business cycle synchronicity (BCS) is analogous to the house price synchronicity measure presented above.

$$
B C S_{i j t}=\frac{\left(Y_{g a p_{i t}}-\overline{Y g a p_{l}}\right)\left(Y_{g a p_{j t}}-\overline{Y g a p_{J}}\right)}{\sigma_{i}^{g a p} \sigma_{j}^{g a p}},
$$

where $Y g a p_{i t}$ and $Y_{g a p}$ represent output gaps of countries $i$ and $j$ respectively at quarter $t$ and the gaps and measured using Christiano and Fitzgerald band-pass filter (2003), with the maximum length adjusted for business cycles instead of financial cycles. $\overline{\operatorname{Ygap}_{\iota}}$ and $\overline{\operatorname{Ygap}_{J}}$ are the average output gaps of countries $i$ and $j$ respectively, while $\sigma_{i}^{g a p}, \sigma_{j}^{g a p}$ are the standard deviations of output gaps of countries $i$ and $j$ respectively.

\section{Bilateral Banking Integration ${ }^{7}$}

Banking integration is measured using bilateral locational banking statistics on residency basis obtained from BIS IBS restricted databases, to be conceptually consistent with balance of payments, national accounts, and external debt statistics. Bilateral banking integration is measured as the logarithm of the sum of bilateral claims of country $i$ vis-à-vis country $j$ and bilateral claims of country $j$ vis-à-vis country $i$ as a ratio of the sum of GDPs of country $i$ and $j^{8}$ :

\footnotetext{
${ }^{5}$ For emerging market economies, we use 20 years as the maximum length instead.

${ }^{6}$ As a robustness check, we also constructed house price gaps using Hodrick and Prescott (1997) filter with a lambda of 400,000 which is commonly used as the lambda relevant for financial cycles. We obtain house price gaps broadly consistent to that of the Christiano and Fitzgerald (CF) filter. CF filter is chosen for our analysis as it computes the cyclical component for all observations without being prone to tail bias.

${ }^{7}$ Additional forms of bilateral financial integration measures such as bilateral portfolio linkages and bilateral direct investment linkages are not used in our analysis due to their lower frequency and shorter time span.

${ }^{8}$ To address the issue of mirror data asymmetry, following Kalemli-Ozcan et al. (2013a; 2013b), we take the average of country $i$ 's assets vis-à-vis country $j$ and county $j$ 's liabilities vis-à-vis country $i$ as the assets of country $i$ vis-à-vis country $j$ and vice versa.
} 


$$
\text { FININT }_{i j t}=\ln \left(\left(\frac{A_{i j t}+A_{j i t}}{G D P_{i t}+G D P}\right) * 100\right)
$$

where $A_{i j t}$ is the bilateral claims of country $i$ vis-à-vis country $j$ at quarter $t, A_{j i t}$ is bilateral claims of country $j$ vis-à-vis country $i, G D P_{i t}$ is the nominal GDP of country $i$ at time $t$, and $G D P_{j t}$ is the nominal GDP of country $j$ at time $t$.

\section{Global Financial Conditions}

We control for the effect of global financial conditions on house price gap synchronicity as common shocks could propagate through global financial stability-related risks. In our main analyses, we focus on changes in Bank of International Settlements' (BIS) global liquidity to capture global financial conditions. This measure captures the changes in banks' cross-border claims denominated in all currencies plus local claims in foreign currency in percent of global GDP. In addition to global liquidity, as robustness checks, we also use global financial conditions index (FCI) and the U.S. FCI estimated in line with IMF (2017). ${ }^{9}$ We also use Chicago Board Options Exchange volatility index (VIX), as well as Wu and Xia (2016) and Krippner (2013) U.S. shadow interest rates to capture global financial conditions in robustness specifications.

\section{E. Other Controls}

To further assess the impact of global financial conditions and bilateral bank linkages when countries have stronger institutions or when they are at different stages of economic development, we use several institutional characteristics and advanced/emerging market economy dummy variables. In particular, we use indicators for high capital account openness (measured using the Chinn-Ito index which is a de jure measure of financial openness), high exchange rate regime (measured using de facto exchange rate regime indices by Ilzetzki, Reinhart, and Rogoff 2017), and high financial openness (measured using the index developed by Lane and Milesi-Ferretti (2007), which is a de facto measure of financial openness) separately in specifications, where high is defined as a dummy variable that equals 1 when both countries in the country-pair are in the top fifth of the institutional characteristic during a given quarter. Dummy variables for advanced economies, emerging market economies, and advanced-emerging market economies take the value of 1 if both countries in the country-pair are either advanced economies, emerging market economies, or advanced-emerging market economies.

\footnotetext{
${ }^{9}$ See Annex 3.2 of the IMF's October 2017 GFSR (Chapter 3) for FCI construction methodology.
} 


\section{Country-Level AnAlysis}

\section{A. Empirical Strategy}

This paper employs bilateral country-pair panel data analysis to estimate the impact of business cycle synchronicity, bilateral financial linkages, and global financial conditions on house price synchronicity at country-level ${ }^{10}$. Our baseline econometric specification presented below is estimated at quarterly frequency from 1990 to 2016 , for 40 countries: ${ }^{11}$

$$
\begin{aligned}
\text { HPsynch }_{i j t}= & \alpha_{i j}+\beta_{1} B C S_{i j t-1}+\beta_{2} \text { FININT }_{i j t-1}+\beta_{3} G L O B A L_{t-1} \\
& +\beta_{4} I N S T_{i j t-1} \times G L O B A L_{t-1}+\beta_{5} I N S T_{i j t-1}+\operatorname{tr}+\varepsilon_{i j t}
\end{aligned}
$$

where HPsynch ${ }_{i j t}$ is the synchronicity of house price gaps between country-pair $i$ and $j$ at quarter $t . B S C_{i j}$ denotes business cycle synchronicity between country $i$ and $j . F I N I N T_{i j}$ refers to bilateral financial integration between country $i$ and $j .{ }^{12} G L O B A L_{t}$ is the global factor proxied by the changes in global liquidity. $I N S T_{i j}$ denote dummies which equal 1 if both countries have a high level of an institutional characteristic (i.e., economic development level, de jure capital account openness, exchange rate flexibility, or de facto financial account openness). ${ }^{13}$ All regressors are lagged by one quarter. In addition, linear and quadratic time trends $(t r)$ are included. $\alpha_{i j}$ is the country-pair fixed effects capturing unobservable time-invariant idiosyncratic factors common to country-pair $i$ and $j$ such as geographic proximity. $\varepsilon_{i j t}$ is the error term. ${ }^{14}$ Importantly, country-pair fixed effects capture time-invariant supply-side and regulatory considerations that influence house price synchronicity between two countries.

\footnotetext{
${ }^{10}$ See Annex II for the analysis on the impact of Bilateral Linkages on House Price Gap Synchronicity.

${ }^{11}$ Although our house price time series, particularly for advanced economies, start several decades prior to 1990, we restrict our econometric analysis to begin in 1990 as the availability of data on bilateral banking linkages significantly improves starting from 1990. We exclude four EMs out of our original sample of 44 countries in the econometric analysis due to the short length of their house price time series.

${ }^{12}$ Financial integration is measured using bilateral locational banking statistics on residency basis obtained from BIS IBS restricted databases. Bilateral banking integration is measured as the logarithm of the sum of bilateral claims of country $i$ vis-à-vis country $j$ and bilateral claims of country $j$ vis-à-vis country $i$ as a ratio of the sum of GDPs of country $i$ and $j$. Additional forms of bilateral financial integration measures such as bilateral portfolio linkages and bilateral direct investment linkages are not used in our analysis due to their lower frequency and much shorter time span.

${ }^{13}$ High level is defined based on the top $1 / 5$ of the distribution of institutional characteristics, at any point in time. In addition, robustness checks were performed by defining the institutional factors as high using $75^{\text {th }}$ or $66^{\text {th }}$ percentile instead of the $80^{\text {th }}$ percentile as cutoff rates.

${ }^{14}$ To account for serial correlation, following Cameron et al. (2011), standard errors are multi-way clustered (at country $i$, country $j$, and time level, where appropriate).
} 


\section{B. Results}

\section{Impact of Global Financial Conditions on House Price Gap Synchronicity}

In our main analyses, we estimate the impact of global financial conditions (also referred to as the global factor) on house price gap synchronicity using the changes in BIS' global liquidity variable mentioned in the preceding section as the proxy for the global factor ${ }^{15}$ and instantaneous quasi-correlation (also mentioned in the previous section) ${ }^{16}$ as the synchronicity measure for house price and business cycle synchronicity. The results presented in Table 1 show that the global financial conditions are positively associated with house price synchronicity even when controlling for bilateral macro financial conditions including business cycle synchronicity and banking integration (column 4). This impact is also robust across various specifications, including where we control for different institutional characteristics and various error clustering methods are considered (see Tables 2-4 for robustness checks). This result could provide preliminary evidence for the positive association between the abundance of global liquidity and short-term co-movements in house price gaps.

Moreover, the impact of the global financial conditions on house price synchronicity appears to be higher between advanced economies than in country-pairs that are emerging market economies (column 5). While the impact of the global financial conditions in advanced economies is statistically significant and positive, neither emerging market economies' nor advanced-emerging market economy-pairs' impact is statistically significant at conventional levels when standard errors are clustered in the most stringent manner.

Institutional characteristics such as higher exchange rate flexibility appear to be attenuating the positive association between global financial conditions and house price synchronicity (column 7). This impact is statistically significant at 1 percent confidence interval. Moreover, it is robust to various controls, as presented in Tables 2-5. We also find an attenuating effect of de jure financial openness (i.e., Chinn-Ito index of capital account openness) on the global financial conditions' impact on house price synchronicity, but the impact of this interaction term is not statistically significant at conventional levels (column 6). Results in columns 4 to 6 are also presented in figure 3 , where we have standardized the coefficients for comparability across specifications.

\footnotetext{
${ }^{15}$ See Table 2 in the robustness checks section for results using additional proxies for global factors.

${ }^{16}$ Given global financial conditions index is more of a short-term indicator, we believe instantaneous quasi-correlation (that purges the mean house price gap) as the synchronicity measure is better suited for this analysis.
} 
Furthermore, the positive impact of global liquidity on house price synchronicity was substantially higher prior to the global financial crisis (GFC). This may provide evidence to the association between the global house price boom that occurred preceding the GFC and the abundance of global liquidity accumulated during that period.

The analysis concerning the impact of bilateral linkages on house price gap synchronicity is presented in Annex II. Using an alternative measure of house price synchronicity, which captures the medium-term dynamics through differences in house price gaps,
Figure 3. Impact of Global Financial Conditions on House Price Synchronization

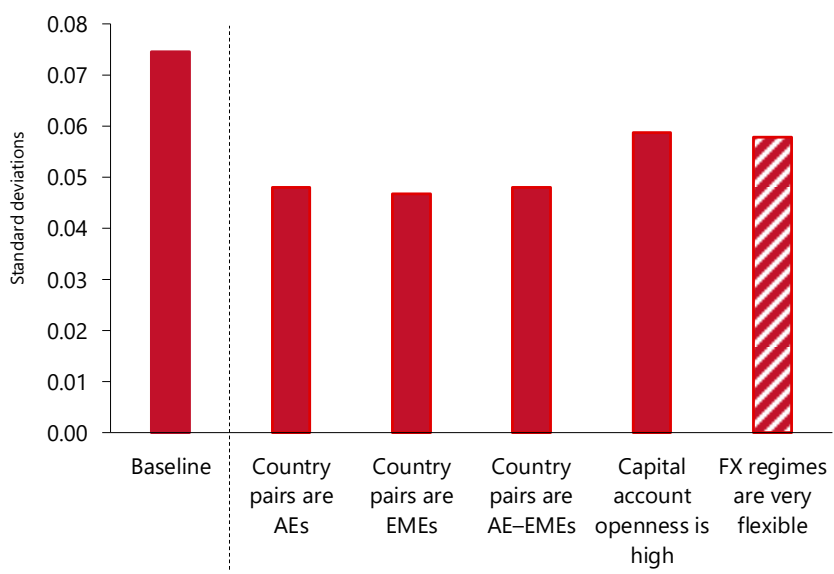

Source: Authors' estimates.

Note: Global financial conditions are proxied by the BIS global liquidity variable mentioned in the previous section. Synchronicity is measured by the quasi correlation of gaps. Shaded bars denote joint significance of the F-test at or above 90 percent. Patterned bars denote interaction terms that are statistically significant. Coefficients are standardized. Standard deviation of the country-level dependent variable is approximately 0.85 (see Annex Table 1.3). AEs = advanced economies; EMEs = emerging market economies; $\mathrm{FX}=$ exchange rate.

we find evidence that both business cycle synchronicity and bilateral banking integration are positively and robustly associated with house price synchronicity.

\section{Robustness Checks}

In addition to the results presented above, various robustness checks were performed, with the main findings broadly unchanged. For instance, alternative proxies for global financial conditions including the U.S. financial conditions index (FCI), Global FCI, CBOE volatility index (VIX), U.S. shadow interest rates (Wu and Xia 2016; Krippner 2013) are used, where the global financial conditions and the high exchange rate regime interaction terms are still found to be statistically significant with the coefficient sign and the size broadly unchanged (Table 2). ${ }^{17}$ Specifications above were also estimated by replacing BCS with interest rate synchronicity to investigate the role of synchronized monetary policies in contributing to house price synchronicity. We find interest rate synchronicity to be a statistically significant driver of house price synchronicity on its own when either synchronicity measure is used (either synch1 or quasi correlation). However, the statistical significance of interest rate synchronicity above and beyond other financial factors such as the global liquidity and

\footnotetext{
${ }^{17}$ While results are robust to these alternative proxies for the global factor, the level of statistical significance declines, especially when the most stringent manner of standard error clustering is considered.
} 
bilateral banking linkages is only robust to less stringent manners of standard error clustering (Table 3, columns 3-6). At the same time, trade integration was included as an additional control, but found not to be statistically significant (Table 3, columns 7-8). When equity price synchronicity is included as an additional control, the main results presented in the previous section remain broadly unchanged (Table 3, columns 9-10). However, equity price synchronicity itself does not consistently have a statistically significant relationship with house price synchronicity.

Various clustering alternatives were employed (clustering at country-pair level, two-way at country $i$ and country $j$, two-way at country-pair and time level, and without clustering, Huber/White/sandwich estimator), and as expected, the level of significance improves under less restrictive clustering options (Table 4). Additional time controls, such as year fixed effects and linear time trends, were also considered with little changes to the main conclusions. Finally, further robustness checks were employed by dropping one country-pair at a time as well. 


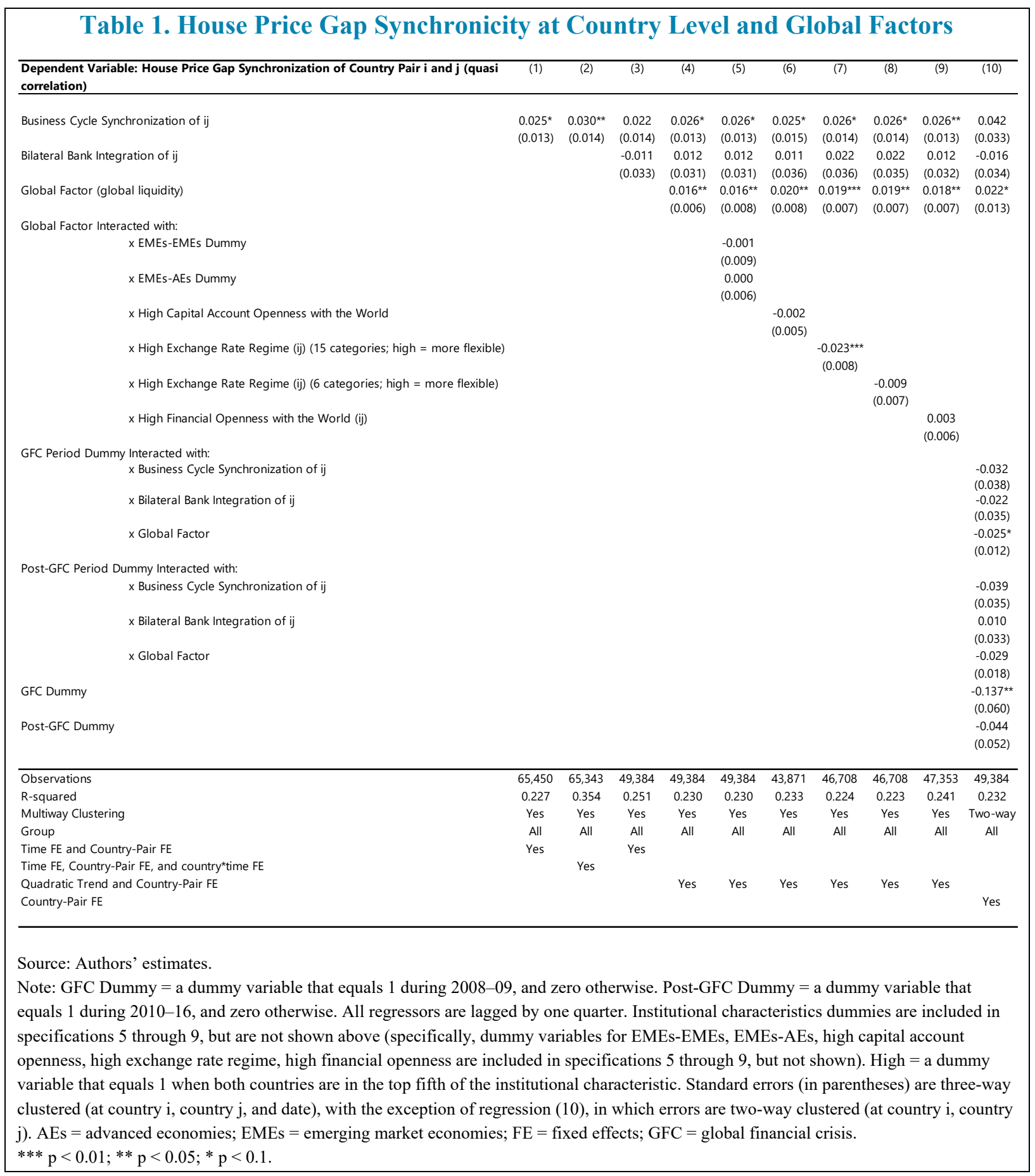

\section{CInternational Monetary Fund. Not for Redistribution}




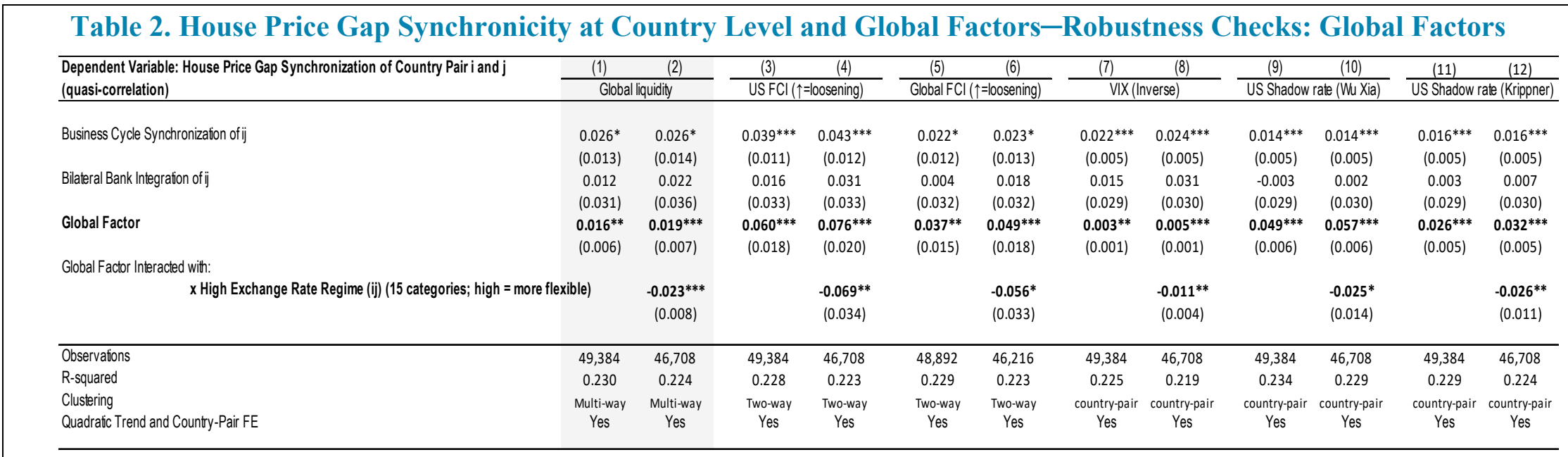

Source: Authors' estimates.

Note: All regressors are lagged by one quarter. Institutional characteristics dummies are included in specifications, but are not shown above (specifically, dummy variables for high exchange rate regime). High $=$ a dummy variable that equals 1 when both countries are in the top fifth of the institutional characteristic. Standard errors (in parentheses) are clustered as described above; FE $=$ fixed effects.

$* * * \mathrm{p}<0.01 ; * * \mathrm{p}<0.05 ; * \mathrm{p}<0.1$.

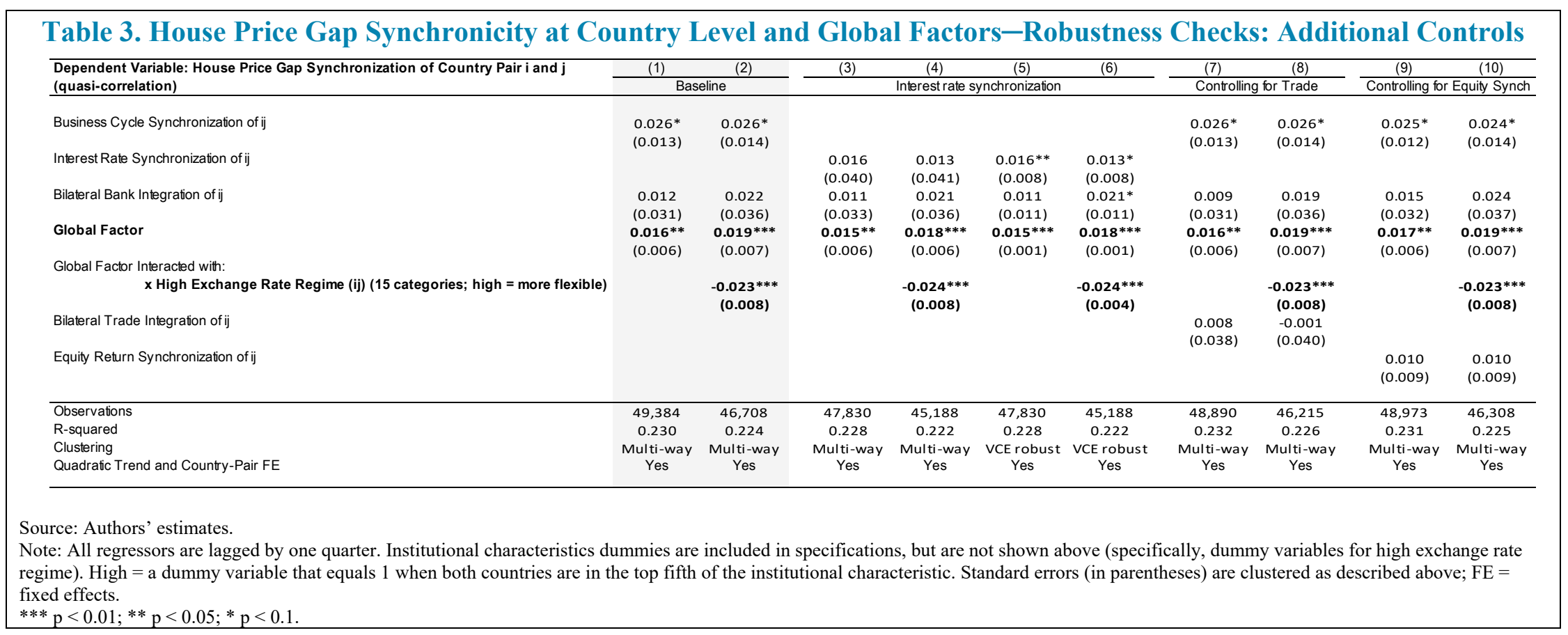




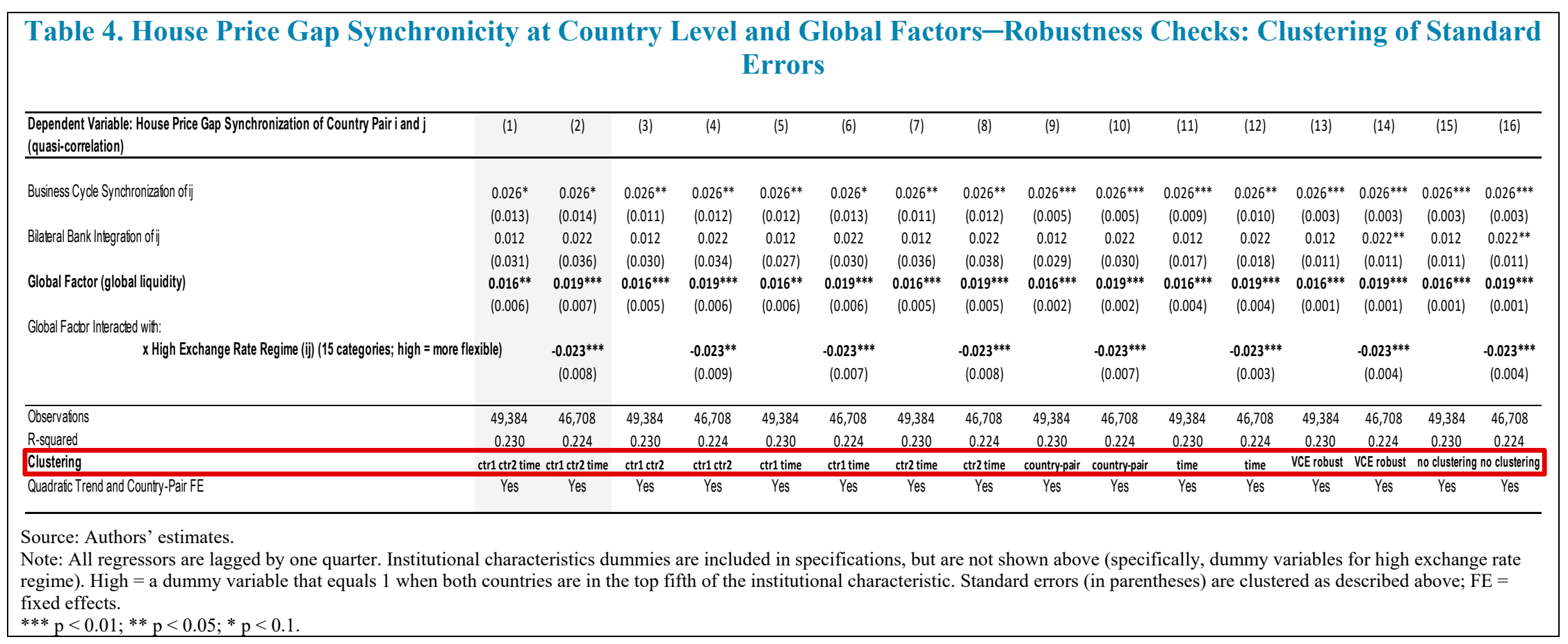




\section{City-Level Analysis}

While house prices synchronicity may vary among country-pairs owing to their degree of exposure to bilateral linkages and global financial conditions as identified in the preceding section, house prices in major cities ${ }^{18}$ may move in tandem due to increasing global presence even if their country-level house prices may not portray such dynamics. To dig deeper into city-level house price synchronicity, we first explore house price interconnectedness dynamics through a network analysis, and then move on to analyzing the drivers of city-level house price synchronicity empirically.

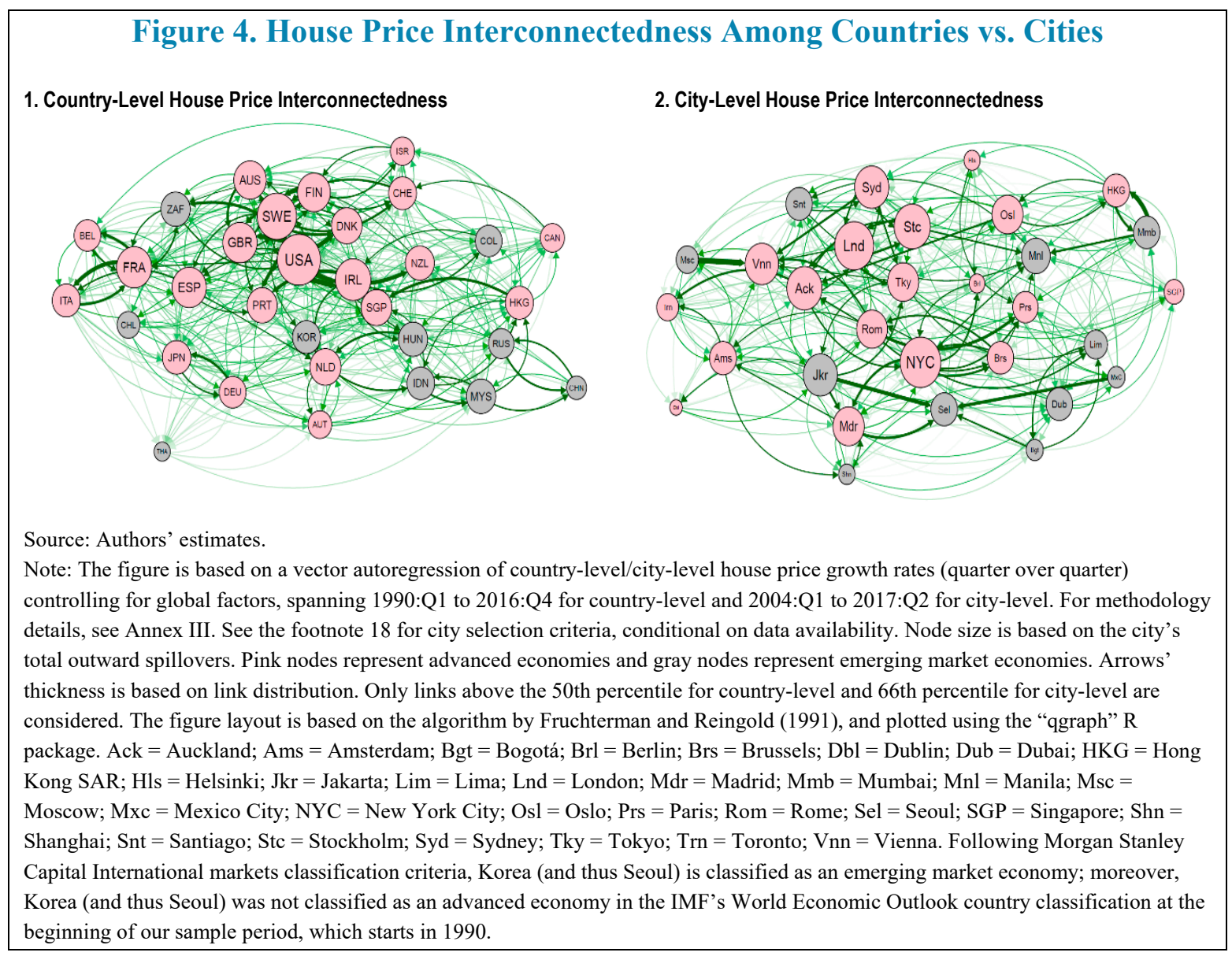

\footnotetext{
18 The selection of cities is based on population and overlaps with the top 50 cities for global investors identified by Cushman \& Wakefield (2017). The sample comprises over 70 cities (see Annex I) combining the Top 30 cities in global investors' ranking by Cushman \& Wakefield's (2017) Global Capital Markets 2017 report, where economic scale, financial center, technology hub, and innovation criteria are considered. If none of the cities in a country (where data are available) are chosen based on the four pillars stated above, the largest city by population in the country is included. Moreover, an additional sample with 44 major cities off the above sample is also constructed.
} 


\section{A. Network Analysis: House Price Interconnectedness at City Level}

Our network analysis uses the spillovers approach developed by Diebold and Yilmaz (2014) (see Annex III for detailed methodology) controlling for global financial conditions (proxied by the U.S. FCI). In fact, comparing the network analysis at country-level and city-level confirms that cities that are attractive to global investors may be at the core of the network and closer to other cities such as financial centers even if the respective countries are at the periphery (Figure 4). For instance, Tokyo and Rome are centrally located in the vicinity of global financial centers such as New York and London in the city-level network map below (Figure 4, Panel 2), while Japan and Italy are located at the periphery of the country-level network map (Figure 4, Panel 1).

\section{B. Empirical Strategy}

The determinants of city-level house price synchronicity are analyzed using a bilateral panel data analysis, where we specifically estimate the impact of country-level measures such as business cycle synchronicity and bilateral financial linkages, and global financial conditions on house price synchronicity within major cities. The analysis is estimated at quarterly frequency from 2004 to 2016 for over 70 major cities ${ }^{19}$. The econometric specification for the city-level analysis takes the following form:

$$
\begin{aligned}
\text { HPsynch }_{i j t}= & \alpha_{i j}+\beta_{1} \text { BCS }_{i j t-1}+\beta_{2} \text { FININT }_{i j t-1}+\beta_{3} G L O B A L_{t-1} \\
& +\beta_{4} I N S T_{i j t-1} \times G L O B A L_{t-1}+\beta_{5} I N S T_{i j t-1}+t r+\varepsilon_{i j t}
\end{aligned}
$$

where HPsynch ${ }_{i j t}$ is the synchronicity of house price gaps between city-pair $i$ and $j$ at quarter $t$. $\alpha_{i j}$ stands for city-pair fixed effects and $t r$ stands for quadratic and linear time trends. GLOBAL $L_{t-1}$ stands for global financial conditions proxied by changes in the BIS' global liquidity in percent of global GDP. All other regressors are country-level variables that are defined in the section on the country-level analysis.

\section{Results}

Similar to our country-level analysis, we use the changes in BIS global liquidity to proxy for the global financial conditions and instantaneous quasi-correlation to measure city-level house price gap synchronicity. We find that global financial conditions are positively associated with city-level house price gap synchronicity; this impact is statistically significant even if standard errors are clustered using a more stringent form of multi-way clustering, while the significance level improves from a 10 percent confidence level to a

\footnotetext{
${ }^{19}$ The coefficients in the regression analysis are weighted by the number of major cities in each country.
} 
1 percent confidence level if two-way clustering is employed instead (column 4 in Tables 5 and 6).

In line with our country-level findings, city-level analysis also confirms that higher exchange rate flexibility tends to be attenuating the positive association between the global factor and the city-level house price synchronicity; this impact is statistically significant at a 5 percent confidence level even when more stringent form of standard error clustering is used (column 7 in Tables 5 and 6).

Furthermore, the impact of global financial conditions on city-level house price synchronicity is higher among city-pairs residing within advanced economies than that of city-pairs residing either within emerging economies or advance-emerging economy pairs (column 5 in Tables 5 and 6). While the impact for advanced economies is statistically significant even when more stringent forms of standard errors are used, the interaction term for advance-emerging pairs is significant only when a less stringent form of clustering is used (such as two-way clustering at country-pair and time level; column 5 in Table 5). The interaction term for emerging economies is not statistically significant when two-way clustering is used.

In contrast to our country-level analysis, the city-level empirical findings suggest that greater financial openness at country-level tends to amplify the positive association between global financial conditions and city-level house price synchronicity. In other words when a de jure measure of financial openness is used (i.e., Chinn-Ito index of capital account openness). However, we find that this impact is not statistically significant if standard errors are clustered in a more stringent manner (column 6 in Table 6). We fail to find statistically significant results when a de facto measure of financial openness is used (i.e., Lane and Milesi-Ferretti (2007) measure of financial openness).

The city-level analysis also confirms that the global financial conditions were positively associated with city-level house price synchronicity prior to the global financial crisis (column 10 in Tables 5 and 6). 


\begin{tabular}{|c|c|c|c|c|c|c|c|c|c|c|}
\hline Dependent Variable: House Price Gap Synchronization of City Pair i and j (quasi-correlation) & (1) & (2) & (3) & (4) & (5) & (6) & (7) & (8) & (9) & (10) \\
\hline Business Cycle Synchronizafion ofij & 0.011 & $0.021^{\star}$ & $\begin{array}{l}0.011 \\
(0.010)\end{array}$ & $\begin{array}{l}0.019^{*} \\
(0.010)\end{array}$ & $\begin{array}{l}0.019^{*} \\
(0.010)\end{array}$ & $\begin{array}{l}0.016 \\
(0.010)\end{array}$ & $\begin{array}{c}0.018 \\
(0.011)\end{array}$ & $\begin{array}{c}0.017 \\
(0.011)\end{array}$ & $\begin{array}{c}0.016 \\
(0.010)\end{array}$ & $\begin{array}{l}0.079^{* * *} \\
(0.027)\end{array}$ \\
\hline Bilateral Bank Integration ofij & & & $\begin{array}{l}0.008 \\
(0.045)\end{array}$ & $\begin{array}{c}0.016 \\
(0.045)\end{array}$ & $\begin{array}{c}0.019 \\
(0.045)\end{array}$ & $\begin{array}{l}0.020 \\
(0.050)\end{array}$ & $\begin{array}{l}0.021 \\
(0.046)\end{array}$ & $\begin{array}{r}0.020 \\
(0.046)\end{array}$ & $\begin{array}{l}0.021 \\
(0.047)\end{array}$ & $\begin{array}{l}0.066 \\
(0.057)\end{array}$ \\
\hline Global Factor (global liquidity) & & & & $\begin{array}{l}0.018^{+*+1+x} \\
(0.005)\end{array}$ & $\begin{array}{l}0.0300^{*+*} \\
(0.008)\end{array}$ & $\begin{array}{l}0.012^{* *} \\
(0.005)\end{array}$ & $\begin{array}{l}0.021^{*+*} \\
(0.006)\end{array}$ & $\begin{array}{l}0.023^{\text {tat }} \\
(0.006)\end{array}$ & $\begin{array}{l}0.018^{+4+x} \\
(0.005)\end{array}$ & $\begin{array}{l}0.024^{* *} \\
(0.009)\end{array}$ \\
\hline Global Factor Interacted with: & & & & & & & & & & \\
\hline $\mathrm{x}$ EMEs-AEs Dummy & & & & & $\begin{array}{l}(0.011) \\
-0.018^{*+*} \\
(0.008)\end{array}$ & & & & & \\
\hline x High Capital Account Openness with the World & & & & & & $\begin{array}{l}0.018^{* *} \\
(0.008)\end{array}$ & & & & \\
\hline x High Exchange Rate Regime (ij) (15 categories; high = more fexible) & & & & & & & $\begin{array}{l}-0.017^{* *} \\
(0.008)\end{array}$ & & & \\
\hline x High Exchange Rate Regime (ij) (6 categories; high = more fexible) & & & & & & & & $\begin{array}{l}-0.012^{*} \\
(0.007)\end{array}$ & & \\
\hline$x$ High Financial Openness with the World (ij) & & & & & & & & & $\begin{array}{c}0.001 \\
(0.016)\end{array}$ & \\
\hline $\begin{array}{l}\text { GFC Period Dummy Interacted with: } \\
\qquad \text { x Business Cycle Synchronization ofij }\end{array}$ & & & & & & & & & & $-0.081^{*+*+x}$ \\
\hline $\mathrm{x}$ Bilateral Bank Integration ofij & & & & & & & & & & $\begin{array}{r}-0.058 \\
0.049\end{array}$ \\
\hline x Global Factor & & & & & & & & & & $\begin{array}{l}-0.025^{* *} \\
(0.010)\end{array}$ \\
\hline Post-GFC Period Dummy Interacled with: & & & & & & & & & & \\
\hline x Business Cycle Synchronization of ij & & & & & & & & & & $\begin{array}{l}-0.078^{+2+x} \\
(0.029)\end{array}$ \\
\hline x Bilateral Bank Integration ofij & & & & & & & & & & $\begin{array}{l}-0.071^{*} \\
(0.040)\end{array}$ \\
\hline$x$ Global Factor & & & & & & & & & & $\begin{array}{l}-0.026^{* *} \\
(0.011)\end{array}$ \\
\hline GFC Dummy & & & & & & & & & & $\begin{array}{c}0.010 \\
(0.038)\end{array}$ \\
\hline PostGFC Dummy & & & & & & & & & & $\begin{array}{c}0.014 \\
(0.049)\end{array}$ \\
\hline Observations & 66,575 & 66,572 & 66,575 & 66,575 & 66,575 & 59,353 & 63,691 & 63,691 & 62,588 & 66,575 \\
\hline R-squared & 0.260 & 0.343 & 0.260 & 0.254 & 0.256 & 0.265 & 0.251 & 0.252 & 0.268 & 0.260 \\
\hline Clustering & Two-way & Two-way & Two-way & Two-way & Two-way & Two-way & Two-way & Two-way & Two-way & Two-way \\
\hline Time FE and County-Pair FE & Yes & & Yes & & & & & & & \\
\hline 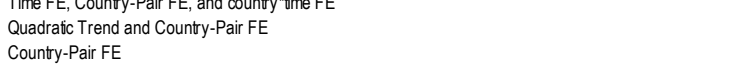 & & & & Yes & Yes & Yes & Yes & Yes & Yes & Yes \\
\hline \multicolumn{11}{|c|}{$\begin{array}{l}\text { Source: Authors' estimates. } \\
\text { Note: GFC Dummy = a dummy variable that equals } 1 \text { during } 2008-09 \text {, and zero otherwise. Post-GFC Dummy = a dummy variable that } \\
\text { equals } 1 \text { curing } 2010-16 \text {, and zero otherwise. All regressors are lagged by one quarter. Institutional characteristics dummies are included in } \\
\text { specifications } 5 \text { through } 9 \text {, but are not shown above (specifically, dummy variables for EMEs-EMEs, EMEs-AEs, high capital account } \\
\text { openness, high exchange rate regime, high financial openness are included in specifications } 5 \text { through } 9 \text {, but not shown). High = a dummy } \\
\text { variable that equals } 1 \text { when both countries are in the top fifth of the institutional characteristic. Standard errors (in parentheses) are two-way } \\
\text { clustered (at country ij, and date). AEs = advanced economies; EMEs = emerging market economies; FE = fixed effects; GFC=global } \\
\text { financial crisis. } \\
* * * \mathrm{p}<0.01 ; * * \mathrm{p}<0.05 ; * \mathrm{p}<0.1 \text {. }\end{array}$} \\
\hline
\end{tabular}

\section{CInternational Monetary Fund. Not for Redistribution}




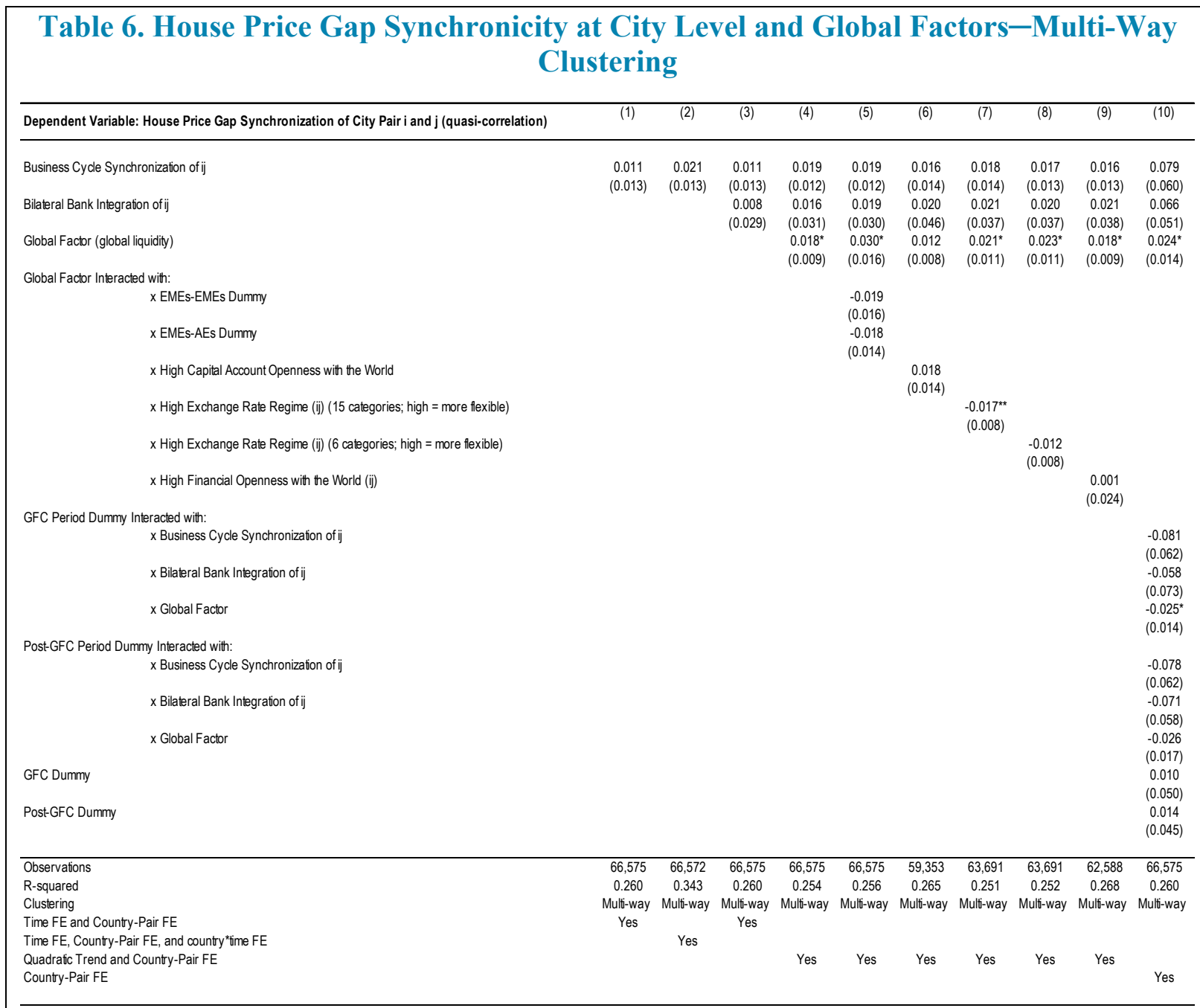

Source: Authors' estimates.

Note: GFC Dummy = a dummy variable that equals 1 during 2008-09, and zero otherwise. Post-GFC Dummy = a dummy variable that equals 1 curing $2010-16$, and zero otherwise. All regressors are lagged by one quarter. Institutional characteristics dummies are included in specifications 5 through 9, but are not shown above (specifically, dummy variables for EMEs-EMEs, EMEs-AEs, high capital account openness, high exchange rate regime, high financial openness are included in specifications 5 through 9 , but not shown). High $=$ a dummy variable that equals 1 when both countries are in the top fifth of the institutional characteristic. Standard errors (in parentheses) are three-way clustered (at country i, country j, and date). AEs = advanced economies; EMEs = emerging market economies; $\mathrm{FE}=$ fixed effects; $\mathrm{GFC}=$ global financial crisis.

$* * * \mathrm{p}<0.01 ; * * \mathrm{p}<0.05 ; * \mathrm{p}<0.1$

\section{CInternational Monetary Fund. Not for Redistribution}




\section{Extensions: The Impact of Macroprudential Policies}

In this section, we focus on the relationship between macroprudential policies (MPPs) and house price synchronicity with regional and global cycles. ${ }^{20}$ MPPs targeted at dampening the accumulation of domestic vulnerabilities in the financial and housing sectors may have indirect effects of weakening the correlation of house price cycles, thereby leaving room for policymakers to regain control over local house price dynamics.

Macroprudential tools, which have been used more actively since the global financial crisis (Alam et al. 2018; Cerutti, Claessens, and Laeven 2015), aim at curbing leverage and reducing financial vulnerabilities in order to decrease the likelihood of domestic asset bubbles and financial crises. MPPs are usually domestically targeted, with a large share of measures focused on domestic credit and housing market conditions. However, in countries experiencing deeper financial integration and where business cycles are more intertwined at the regional and global levels, house prices are, in part, driven by other factors, such as capital flows from global investors and by global financial conditions. ${ }^{21}$ Thus, the relationship between macroprudential tools and house price synchronicity might be ambiguous because it may be offset by other factors.

Recent empirical literature (Vandenbussche, Vogel, and Detragiache 2015; Cerutti, Dagher, and Dell'Ariccia 2015) suggests that the role of macroprudential policies in mitigating house prices is less clear and may vary according to policy type. For instance, measures targeting housing finance (Akinci and Olmstead-Rumsey 2017) and those that complement monetary policy (Bruno, Shim, and Shin 2017) seem to be most effective in mitigating house price growth. In contrast, there is no robust evidence for policies such as riskweighting and provisioning requirements (Kuttner and Shim 2016).

\section{A. Empirical Strategy}

The analysis gauges the effectiveness of macroprudential tools in reducing house price synchronicity across 41 countries from the second quarter of 1990 through the last quarter of 2016. More specifically, the following panel regression specification is estimated, with $i$ denoting country and $t$ representing quarter:

\footnotetext{
${ }^{20}$ Synchronicity with regional cycles may pose further financial stability concerns, as macro-financial shocks could transmit more easily from one country to another through interconnected bank balance sheets and collateral values. In some regions, house price synchronicity with the regional cycle is stronger than with the global cycle, reflecting deeper intra-regional financial and trade integration (see also Katagiri 2018). As depicted in Annex Figure 1.2., we find that the median correlation with the global cycle is roughly 0.4 , while the one with the regional cycle is about 0.5 across all countries and time.

${ }^{21}$ House price synchronicity with the global cycle is heterogeneous across regions, potentially reflecting deeper intraregional financial and trade integration.
} 


$$
H P S_{i, t}=\rho B C S_{i, t-1}+\beta M P P_{i, t-1}+\gamma X_{i, t-1}+\alpha_{i}+\epsilon_{i, t}
$$

where $\alpha_{i}$ denotes country fixed effects. The dependent variable HPS refers to house price cycle synchronicity (instantaneous quasi-correlation) with either the regional or the global cycle. $B C S$ is business cycle synchronicity with the region or the rest of the world. $X$ is a vector of controls (including global financial conditions, financial integration with the region or the world, and institutional characteristics). $M P P$ is a macroprudential tool (such as limits to loan-to-value ratios or debt-to-income ratios, or fiscal-based measures that include sellers' and buyers' stamp duty taxes) or a macroprudential group index (such as loan-targeted, supply-side [capital, general, loans], or demand-side tools). ${ }^{22}$

\section{B. Results}

House price growth evolved differently after the adoption of demand-side MPPs such as loan-to-value (LTV) limits, depending on the level of synchronicity (Figure 5). Before the adoption of these policies, house prices grew similarly in countries with high or low house price synchronicity. Following the adoption of MPPs, house price growth declined in both groups of countries, but the decline was stronger and more sustained in
Figure 5. Average House Price Growth and Demand-side Macroprudential Policies

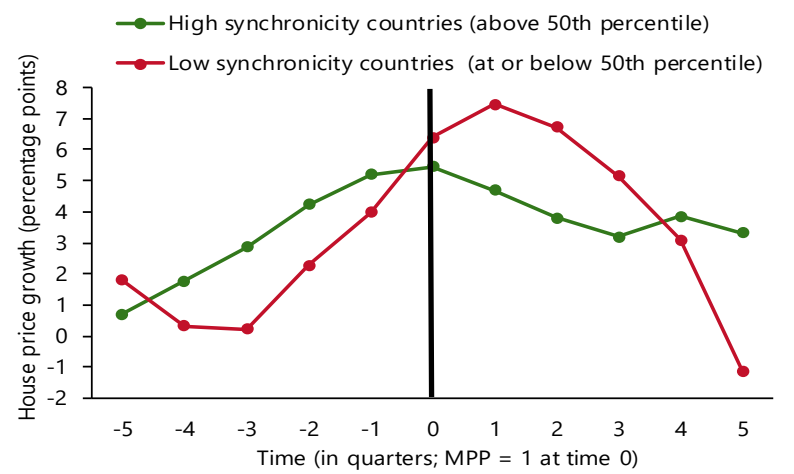

Source: Authors' estimates.

Note: The figure depicts the average year-over-year house price growth for highsynchronicity and low-synchronicity countries within a period of plus or minus five quarters around the implementation of demand-side macroprudential policies (MPPs). Demand-side MPPs include limits to debt-service-to-income and loan-to-value (LTV) ratios. Total number of demand-side events is 47 , and $t=0$ is identified as the first quarter in which demand-side MPPs were implementated within the plus-or-minus-fivequarter window. Synchronicity is based on the quasi-correlation of house price gaps with the global cycle. A country is classified in the high-synchronicity group when its average syncronicity (over the sample period) with the global cycle is above the 50th percentile in the sample, and vice versa.

low-synchronicity countries. These simple patterns suggest that policymakers may have more control over the dynamics of the housing markets in low-synchronicity countries. At the same time, it suggests that a high degree of synchronicity does not render MPPs ineffective. This could be the case if the financial factors behind house price synchronicity operate, at least partially, through local financial intermediaries.

MPPs are also associated with a reduction in house price synchronicity (Figure 6, Panel 1 and Annex Table 4.1); in fact, tighter macroprudential tools targeting bank capital and credit

${ }^{22}$ For more details regarding the macroprudential tools database, see Alam et al. (2018). 
conditions are found to be associated with lower house price synchronicity. Since these tools mostly affect local financial intermediaries and domestic demand, this finding also suggests that factors driving house price co-movement operate, to some degree, through these channels. The relationship between capital-based measures, which include countercyclical capital buffers, and house price synchronicity seems the most highly negative. Likewise, loan-targeted measures, including LTV limits, and supply-side loan-targeted tools, such as limits on foreign currency, are found to lessen correlations with the global and regional house price cycles. The adoption of fiscal-based measures, such as ad valorem and buyer's stamp duty taxes that could potentially deter global investors from engaging in speculative real estate purchases is also associated with a decline in synchronicity, but to a lesser extent than other MPPs. ${ }^{23}$ When looking only at periods with credit booms, the results are both qualitatively and quantitatively similar, although the relationships are slightly less significant (Figure 6, panel 2 and Annex Table 4.2).

\section{Figure 6. Impact of Macroprudential Measures on House Price Synchronicity}

Loan-specific measures such as LTV limits seem effective in reducing synchronicity with both the region and the global cycle.
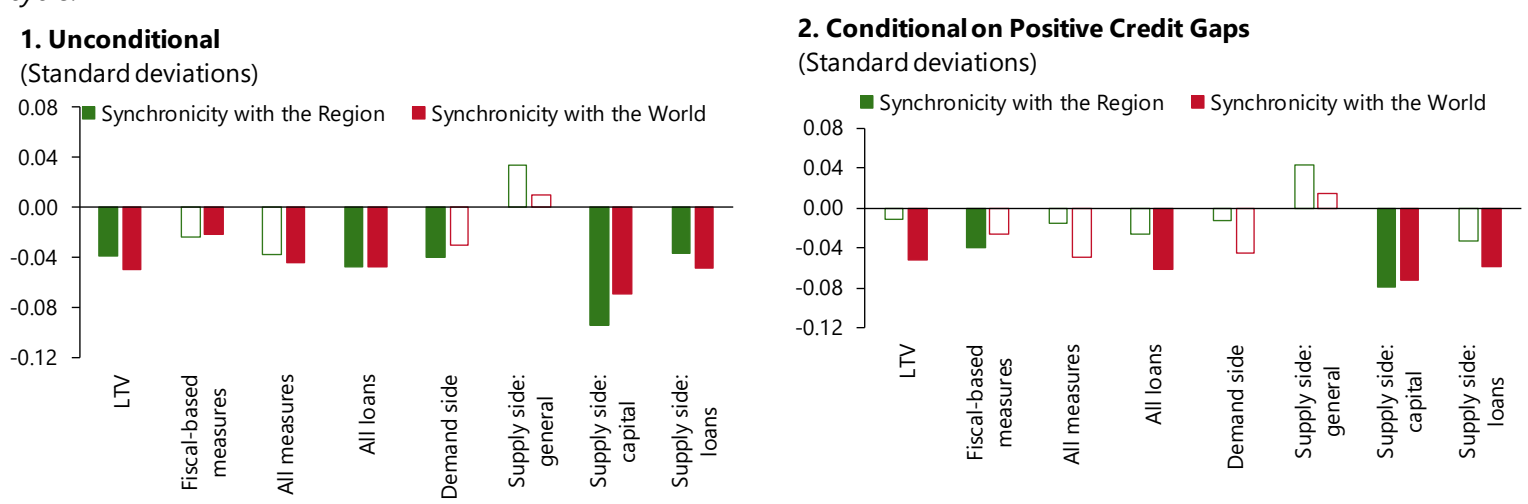

Source: Authors' estimates.

Note: Figure depicts estimated average effects of macroprudential tools on house price synchronicity with the regional cycle (green) and global cycle (red). Shaded bars show statistically significant standardized coefficients, at the 10 percent confidence level. Estimated panel regressions use data for 41 countries (panel 1) spanning over 1990:Q2 - 2016:Q4 period. Regressions control for business cycle synchronicity, financial integration, and global financial conditions. All regressors are lagged one quarter. Supply side (loans) consists of limits on credit growth, loan loss provisions, loan restrictions, and limits on foreign currency loans. Supply side (capital) consists of capital requirements, conservation buffers, the leverage ratio, and the countercyclical capital buffer. Supply side (general) consists of reserve requirements, liquidity requirements, and limits on foreign exchange positions. Demand-side includes limits to debt-service-toincome and LTV ratios. All loans measures include demand side and supply side (loans). Fiscal-based measures include taxes such as ad valorem, seller's and buyer's stamp duty, or other taxes.

\footnotetext{
${ }^{23}$ In some instances, fiscal-based measures target speculative investments, including by foreign buyers (see IMF 2018b).
} 


\section{Conclusions}

Using various proxies for global financial conditions, this paper confirms that the abundance of liquidity owing to accommodative financial conditions is positively associated with house price synchronicity at country and city levels. While higher house price synchronicity may benefit countries in some cases, positive association with global financial conditions could also suggest a stronger transmission of external shocks into the domestic economy or to major cities within an economy. Moreover, house price synchronicity dynamics among major cities may vary from that of their respective countries' owing to the attractiveness of these cities to global investors. Our analysis also finds that the positive association of global financial conditions with house price synchronicity was stronger preceding the global financial crisis.

Countries with more flexible exchange rate regimes, on average, may possess the ability to attenuate the positive impact of global financial conditions on house price synchronicity. Moreover, our empirical analysis suggests that major cities located in countries with more flexible exchange rate regimes possess the ability of attenuating the impact of global financial conditions on city-level house price synchronicity as well.

Finally, we find that house price growth in countries that experience lower house price synchronicity with the rest of the world, on average, are more sensitive to macroprudential policies that are aimed at reducing domestic vulnerabilities, compared to high synchronicity countries. However, our empirical analysis suggests that macroprudential policies intended at addressing domestic vulnerabilities also possess the unintended effect of reducing house price synchronicities, thereby allowing policymakers to regain partially control over local house price dynamics. 


\section{REFERENCES}

Akinci, Ozge, and Jane Olmstead-Rumsey. 2017. "How Effective Are Macroprudential Policies? An Empirical Investigation.” Journal of Financial Intermediation 33 (January): $33-57$.

Alam, Zohair, Adrian Alter, Jesse Eiseman, Gaston Gelos, Heedon Kang, Machiko Narita, Erlend Nier, and Naixi Wang. 2018. "Digging Deeper-Evidence on the Effects of Macroprudential Policies from a New Database.” IMF Working Paper, International Monetary Fund, Washington, DC.

Allen, Franklin, and Douglas Gale. 2000. "Financial Contagion." Journal of Political Economy 108 (1): 1-33.

Badarinza, Cristian, and Tarun Ramadorai. 2018. "Home away from Home? Foreign Demand and London House Prices.” Journal of Financial Economics, July (26): 21-34.

Bernanke, Ben, Carol C. Bertaut, Laurie Demarco, and Steven B. Kamin. 2011.

"International Capital Flows and the Return to Safe Assets in the United States, 2003-2007." FRB International Finance Discussion Paper 1014, Federal Reserve Board, Washington, DC.

Bruno, Valentina, Ilhyock Shim, and Hyun Song Shin. 2017. "Comparative Assessment of Macroprudential Policies.” Journal of Financial Stability 28: 183-202.

Cameron, A. Colin, Jonah B. Gelbach, and Douglas L. Miller. 2011. "Robust Inference with Multi-Way Clustering.” Journal of Business Economics 29: 238-49.

Cerutti, Eugenio, Stijn Claessens, and Luc Laeven. 2015. "The Use and Effectiveness of Macroprudential Policies: New Evidence.” Journal of Financial Stability 28 (C): 203-24.

Cerutti, Eugenio, Jihad Dagher, and Giovanni Dell'Ariccia. 2017. "Housing Finance and Real-Estate Booms: A Cross-Country Perspective.” Journal of Housing Economics 38 (C): $1-13$.

Chinn, Menzie D., and Hiro Ito. 2006. "What Matters for Financial Development? Capital Controls, Institutions, and Interactions." Journal of Development Economics 81 (1): 163-92.

Christiano, Lawrence J., and Terry J. Fitzgerald. 2003. “The Band Pass Filter.” International Economic Review 44 (2): 435-65. 
Claessens, Stijn, M. Ayhan Kose, and Marco E. Terrones. 2008. "What Happens during Recessions, Crunches and Busts?” IMF Working Paper 08/274, International Monetary Fund, Washington, DC.

—. 2011a. "Financial Cycles: What? How? When?” IMF Working Paper 11/76, International Monetary Fund, Washington, DC.

_. 2011b. "How Do Business and Financial Cycles Interact?" IMF Working Paper 11/88, International Monetary Fund, Washington, DC.

Cushman \& Wakefield. 2017. "Winning in Growth Cities.” December 19. https:// cushmanwakefield.turtl.co/story/59d48cf5d1c76a6148cabb4f.

Demirer, Mert, Francis X. Diebold, Laura Liu, and Kamil Yilmaz. 2018. "Estimating global bank network connectedness." Journal of Applied Econometrics 33 (1): 1-15.

Diebold, Francis X., and Kamil Yilmaz. 2014. "On the Network Topology of Variance Decompositions: Measuring the Connectedness of Financial Firms.” Journal of Econometrics 182 (1): 119-34.

Duval, Romain, Nan Li, Richa Saraf, and Dulani Seneviratne. 2016. "Value-Added Trade and Business Cycle Synchronization.” Journal of International Economics 99 (March): $251-62$.

Fruchterman, Thomas M. J., and Edward M. Reingold. 1991. "Graph Drawing by ForceDirected Placement.” Software: Practice and Experience 21 (11): 1129-64.

Hirata, Hideaki, M. Ayhan Kose, Christopher Otrok, and Marco E. Terrones. 2012. "Global house price fluctuations: Synchronization and determinants.” Working Paper No. w18362, National Bureau of Economic Research.

Hodrick, Robert J., and Edward Prescott. 1997. "Postwar U.S. Business Cycles: An Empirical Investigation.” Journal of Money, Credit, and Banking 29 (1): 1-16.

International Monetary Fund (IMF). 2013. "Dancing Together? Spillovers, Common Shocks, and the Role of Financial and Trade Linkages." World Economic Outlook, October, Washington, DC. 
_. 2016. "The Growing Importance of Financial Spillovers from Emerging Market Economies.” Global Financial Stability Report, April, Washington, DC.

- 2017. "Financial Conditions and Growth at Risk." Global Financial Stability Report, October, Washington, DC.

_. 2018a. "House Price Synchronization: What Role for Financial Factors?" Global Financial Stability Report, April, Washington, DC.

- 2018b. "People's Republic of China-Hong Kong Special Administrative Region: Selected Issues.” IMF Country Report 18/17, International Monetary Fund, Washington, DC.

Ilzetzki, Ethan, Carmen M. Reinhart, and Kenneth S. Rogoff. 2017. "Exchange Rate Arrangements Entering the 21st Century: Which Anchor Will Hold?" NBER Working Paper 23134, National Bureau of Economic Research, Cambridge, MA.

Jordà, Òsca, Katharina Knoll, Dmitry Kuvshinov, Moritz Schularick, and Alan Taylor. 2017. “The Rate of Return on Everything, 1870-2015." NBER Working Paper 24112, National Bureau of Economic Research, Cambridge, MA.

Kalemli-Özcan, Sebnem, Elias Papaioannou, and Fabrizio Perri. 2013a. "Global Banks and Crisis Transmission.” Journal of International Economics 89 (2): 495-510.

Kalemli-Özcan, Sebnem, Elias Papaioannou, and José-Luis Peydró. 2013b. "Financial Regulation, Financial Globalization, and the Synchronization of Economic Activity.” Journal of Finance 68 (3): 1179-228.

Katagiri, Mitsuru. 2018. "House Price Synchronization and Financial Openness: A Dynamic Factor Model Approach.” IMF Working Paper 18/209, International Monetary Fund, Washington, DC.

Krippner, Leo. 2013. "Measuring the Stance of Monetary Policy in Zero Lower Bound Environments." Economics Letters 118 (1): 135-38.

Kuttner, Kenneth N., and Ilhyock Shim. 2016. "Can Non-Interest Rate Policies Stabilize Housing Markets? Evidence from a Panel of 57 Economies.” Journal of Financial Stability 26 (October): $31-44$. 
Landier, Augustin, David Sraer, and David Thesmar. 2017. "Banking Integration and House Price Co-movement." Journal of Financial Economics 125 (1): 1-25.

Lane, Philip, and Gian-Maria Milesi-Ferretti. 2007. "The External Wealth of Nations Mark II: Revised and Extended Estimates of Foreign Assets and Liabilities, 1970-2004.” Journal of International Economics 73 (2): 223-50.

Longstaff, Francis. 2010. "The Subprime Credit Crisis and Contagion in Financial Markets." Journal of Financial Economics 97: 436-450.

Morgan, Donald, Bertrand Rime, and Philip Strahan. 2004. "Bank Integration and State Business Cycles.” Quarterly Journal of Economics 119 (4): 1555-85.

Song, Song, and Peter J. Bickel. 2011. "Large Vector Auto Regressions." Working Paper SFB649DP2011-048, Humboldt University, Collaborative Research Center 649.

Terrones, Marco. 2004."The Global House Price Boom," IMF World Economic Outlook, September, pp.71-136.

Wu, Jing Cynthia, and Fan Dora Xia. 2016. "Measuring the Macroeconomic Impact of Monetary Policy at the Zero Lower Bound.” Journal of Money, Credit and Banking 48 (2-3): 253-91.

Vandenbussche, Jerome, Ursula Vogel, and Enrica Detragiache. 2015. "Macroprudential Policies and Housing Prices: A New Database and Empirical Evidence for Central, Eastern, and Southeastern Europe.” Journal of Money, Credit and Banking 47 (S1): 343-77. 


\section{AnNeX I: DAta Sources, Coverage, ANd Summary Statistics}

Annex Table 1.1. Data Sources

\begin{tabular}{|c|c|c|}
\hline Variable & Description & Source \\
\hline \multicolumn{3}{|l|}{ Country-Level Variables } \\
\hline Real House Price Indices & Residential property prices (seasonally adjusted) at country level (also at city level) & $\begin{array}{l}\text { Bank for International Settements; CEIC Data Co. Ltd; Emerging Markets Econom } \\
\text { Data Ltd; Global Financial Data Solutions; Global Property Guide; Haver Analytics } \\
\text { IMF, Research Department house price dataset, Organisation for Economic Co- } \\
\text { operation and Development, Thomson Reuters Datastream; IMF staff calculations }\end{array}$ \\
\hline Real House Price Indices (long historical) & Annual nominal house prices starting 1870 for 17 advanced economies (adjusted for inflation) & Jordà-Schularick-Taylor Macrohistory database; IMF staff calculations \\
\hline Real GDP & GDP at constant prices, seasonally adjusted & $\begin{array}{l}\text { Haver Analytics; Organisation for Economic Co-operation and Development, IMF, } \\
\text { Global Data Source database; IMF, World Economic Outook database }\end{array}$ \\
\hline Real GDP (long historical) & Annual real GDP starting 1870 for 17 advanced economies & Jordà-Schularick-Taylor Macrohistory database \\
\hline Nominal GDP & GDP at current prices, seasonally adjusted (both in national currency and US dollars) & $\begin{array}{l}\text { Haver Analytics; Organisation for Economic Co-operation and Development, IMF, } \\
\text { Global Data Source database; IMF, World Economic Outlook database }\end{array}$ \\
\hline Inflation & Percent change in the consumer price index & Haver Analytics; IMF, Global Data Source database; IMF staff calculations \\
\hline Inflation (long historical) & Percent change in the consumer price index for 17 advanced economies starting 1870 & Jordà-Schularick-Taylor Macrohistory database \\
\hline Total Bank Claims and Liabilities & Total locational assets and liabilities vis-à-vis the world in percent of GDP & Bank for International Settements; IMF staff calculations \\
\hline Financial Openness & Foreign assets plus foreign liabilities in percent of GDP & Lane Milesi-Ferretti dataset (2007; updated) \\
\hline Capital Account Openness & Chin-Ito index, measuring a county's degree of capital account openness & Chinn and lto (2006) dataset (updated) \\
\hline Exchange Rate Regime & De facto exchange rate regime of a country (variables based on 15 categories and 6 categories are used) & Ilzetzki, Reinhart, and Rogoff (2017) dataset \\
\hline Macroprudential Policies & Macroprudential policy tools at quarterly frequency & Alam and others (forthcoming) \\
\hline \multicolumn{3}{|l|}{ Bilateral-Level Variables } \\
\hline $\begin{array}{l}\text { Bilateral Bank Claims vis-à-vis Counterparty } \\
\text { Economies }\end{array}$ & Bilateral locational cross-border claims on residency basis & Bank for International Settements International Banking Statistics confidential datab: \\
\hline $\begin{array}{l}\text { Bilateral Gross Trade vis-à-vis Counterparty } \\
\text { Economies }\end{array}$ & Gross exports vis-à-vis counterparty economies & IMF, Direction of Trade database; IMF staff calculations \\
\hline \multicolumn{3}{|l|}{ Global-Level Variables } \\
\hline Global Liquidity & Total claims of all Bank for International Settements reporters vis-à-vis the world, in percent of world GDP & Bank for International Settlements; Haver Analytics \\
\hline US Financial Conditions Index & $\begin{array}{l}\text { Positive values of the } \mathrm{FCl} \text { indicate ighter-than-average financial conditions. For methodology and variables } \\
\text { included in the } \mathrm{FCl} \text {, refer to Annex } 3.2 \text { of the October } 2017 \text { Global Financial Stability Report. }\end{array}$ & IMF, October 2017 Global Financial Stability Report (Chapter 3) \\
\hline Global Financial Conditions Index & $\begin{array}{l}\text { Based on a PCA of all FCls estimated; Positive values of the FCl indicate tighter-than-average financial } \\
\text { conditions. For methodology and variables included in the FCl, refer to Annex } 3.2 \text { of the October } 2017 \\
\text { Global Financial Stability Report. }\end{array}$ & IMF, October 2017 Global Financial Stability Report (Chapter 3) \\
\hline VIX & Chicago Board Options Exchange Volatility Index & Haver Analytics \\
\hline US Shadow Interest Rates & Wu-Xia and Krippner Shadow Federal Funds Rates & Bloomberg Finance L.P.; Haver Analytics \\
\hline
\end{tabular}

Source: Authors.

Note: FCI = financial conditions index; PCA = principal component analysis; VIX = Chicago Board Options Exchange Volatility Index. 


\section{Annex Figure 1.1. Sample Coverage}

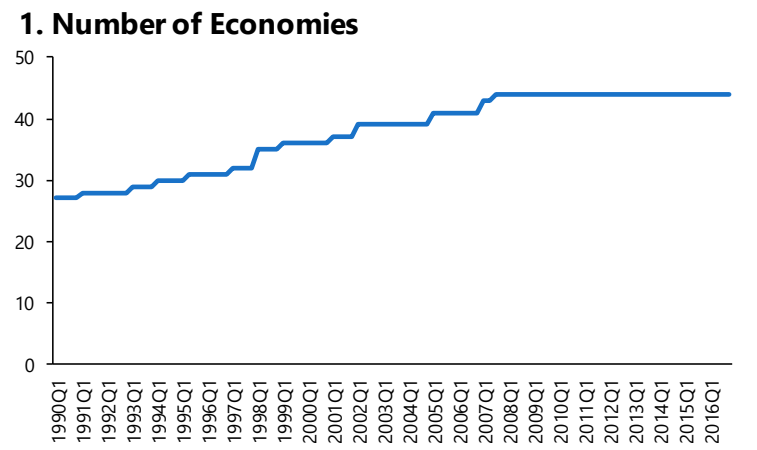

\section{Number of Cities}

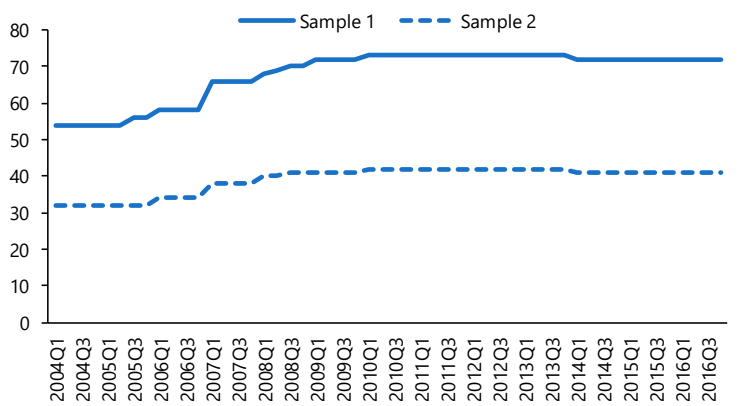

Source: Authors' calculations.

Note: Cities selected are the largest cities based on population, and overlap with the top 50 cities for global investors identified by Cushman \& Wakefield (2017). The sample comprises over 70 cities based on the top 30 cities for global investors in Cushman \& Wakefield's (2017) Global Capital Markets 2017 report's economic scale, financial center, technology hub, and innovation pillars are also used in robustness checks. If none of the cities in a country (where data are available) are chosen based on the four pillars stated above, the largest city by population in the country is included. Moreover, an additional sample with 44 major cities is also constructed.

\begin{tabular}{|c|c|c|c|}
\hline \multicolumn{4}{|c|}{ Annex Table 1.2. List of Economies and Cities in the Analysis } \\
\hline \multicolumn{4}{|c|}{ Economies } \\
\hline Australia & Euro area & Italy & Singapore \\
\hline Austria & Finland & Japan & Slovenia \\
\hline Belgium & France & Korea & South Africa \\
\hline Canada & Germany & Malaysia & Spain \\
\hline Chile & Greece & Mexico & Sweden \\
\hline China & Hong Kong SAR & Netherlands & Switzerland \\
\hline Colombia & Hungary & New Zealand & Taiwan Province of China \\
\hline Cyprus & India & Norway & Thailand \\
\hline Czech Republic & Indonesia & Portugal & Turkey \\
\hline Denmark & Ireland & Russia & United Kingdom \\
\hline Estonia & Israel & Serbia & United States \\
\hline \multicolumn{4}{|c|}{ Cities $^{1}$} \\
\hline Amsterdam* ${ }^{*}$ & Dublin* & Manila* & Seattle \\
\hline Athens ${ }^{*}$ & Dusseldorf & Melbourne & Shanghai* \\
\hline Attanta & Frankfurt & Mexico City ${ }^{*}$ & Shenzhen \\
\hline Auckland* & Guangzhou & Miami & Singapore (core central region) ${ }^{*}$ \\
\hline Austin & Greater Stockholm* & Milan & Suzhou \\
\hline Bangkok* & Hamburg & Montreal & Sydney* \\
\hline Barcelona & Finland metro area* & Moscow* & Taipei* $^{*}$ \\
\hline Beijing & Hong Kong SAR (urban areas)* & Mumbai* $^{*}$ & Tallinn* \\
\hline Belgrade $^{*}$ & Houston & Munich & Tianjin \\
\hline Berlin* & Inner Paris ${ }^{*}$ & Nagoya & Tokyo* \\
\hline Bogotá* & |stanbu|* & New York* & Toronto* \\
\hline Boston & Jakarta* $^{*}$ & Osaka & Vancouver \\
\hline Brussels* & Kuala Lumpur* & Oslo* & Vienna* \\
\hline Budapest" & Lake Geneva Area & Philadelphia & Washington DC \\
\hline Buenos Aires* & Lima* $^{*}$ & Prague $^{*}$ & Zurich* \\
\hline Chicago & Lisbon* & Rome $^{*}$ & \\
\hline Copenhagen ${ }^{*}$ & Ljubljana* & San Francisco & \\
\hline Dallas & London* & South Santiago* & \\
\hline Delhi & Los Angeles & Southern Seoul ${ }^{*}$ & \\
\hline Dubai $^{*}$ & Madrid* & São Paulo* & \\
\hline
\end{tabular}

Source: Authors' calculations.

${ }^{1}$ See the Annex Figure 1.1 note above for city selection criteria. Cities with asterics are included in the smaller sample. 


\begin{tabular}{|c|c|c|}
\hline \multicolumn{3}{|c|}{ Annex Table 1.3. Standard Deviations of the Variables Used in Empirical Analyses } \\
\hline & Country-level & City-level \\
\hline House price synchronization [Synch1] & 0.10 & 0.10 \\
\hline Business cycle synchronization [Synch1] & 0.01 & 0.02 \\
\hline House price synchronization [Quasi-correlation] & 0.84 & 0.99 \\
\hline Business cycle synchronization [Quasi-correlation] & 1.33 & 1.28 \\
\hline Bilateral bank integration of ij & 1.04 & 0.97 \\
\hline Global factor (global liquidity) & 3.90 & 4.48 \\
\hline Global liquidity : AE-AE pairs & 2.51 & 3.09 \\
\hline Global liquidity : EM-EM pairs & 0.95 & 0.95 \\
\hline Global liquidity : AE-EM pairs & 2.84 & 3.10 \\
\hline Global liquidity : Sample with high capital account openness & 2.84 & 3.25 \\
\hline Global liquidity : Rest of the sample & 2.77 & 3.22 \\
\hline Global liquidity : Sample with high FX regime & 1.01 & 1.93 \\
\hline Global liquidity : Rest of the sample & 3.76 & 4.04 \\
\hline Global liquidity : Sample with high financial openness & 1.11 & 0.71 \\
\hline Global liquidity : Rest of the sample & 3.81 & 4.52 \\
\hline Global liquidity : Pre-crisis sample & 2.13 & 1.99 \\
\hline Global liquidity : GFC sample & 2.24 & 5.84 \\
\hline Global liquidity : Post-GFC sample & 1.62 & 2.31 \\
\hline \multicolumn{3}{|l|}{ Analysis on the Impact of Macroprudential Policies: } \\
\hline House price synchronization with the region [Quasi-correlation] & 0.99 & $\ldots$ \\
\hline House price synchronization with the world [Quasi-correlation] & 0.97 & $\ldots$ \\
\hline LTV & 0.39 & $\ldots$ \\
\hline Fiscal-based measures & 0.17 & $\ldots$ \\
\hline All measures & 1.36 & $\ldots$ \\
\hline All loans & 0.73 & $\ldots$ \\
\hline Demand side & 0.51 & $\ldots$ \\
\hline Supply side & 1.02 & $\ldots$ \\
\hline Supply side: general & 0.79 & $\ldots$ \\
\hline Supply side: capital & 0.40 & $\ldots$ \\
\hline Supply side: loans & 0.39 & $\ldots$ \\
\hline
\end{tabular}

\section{(C)International Monetary Fund. Not for Redistribution}




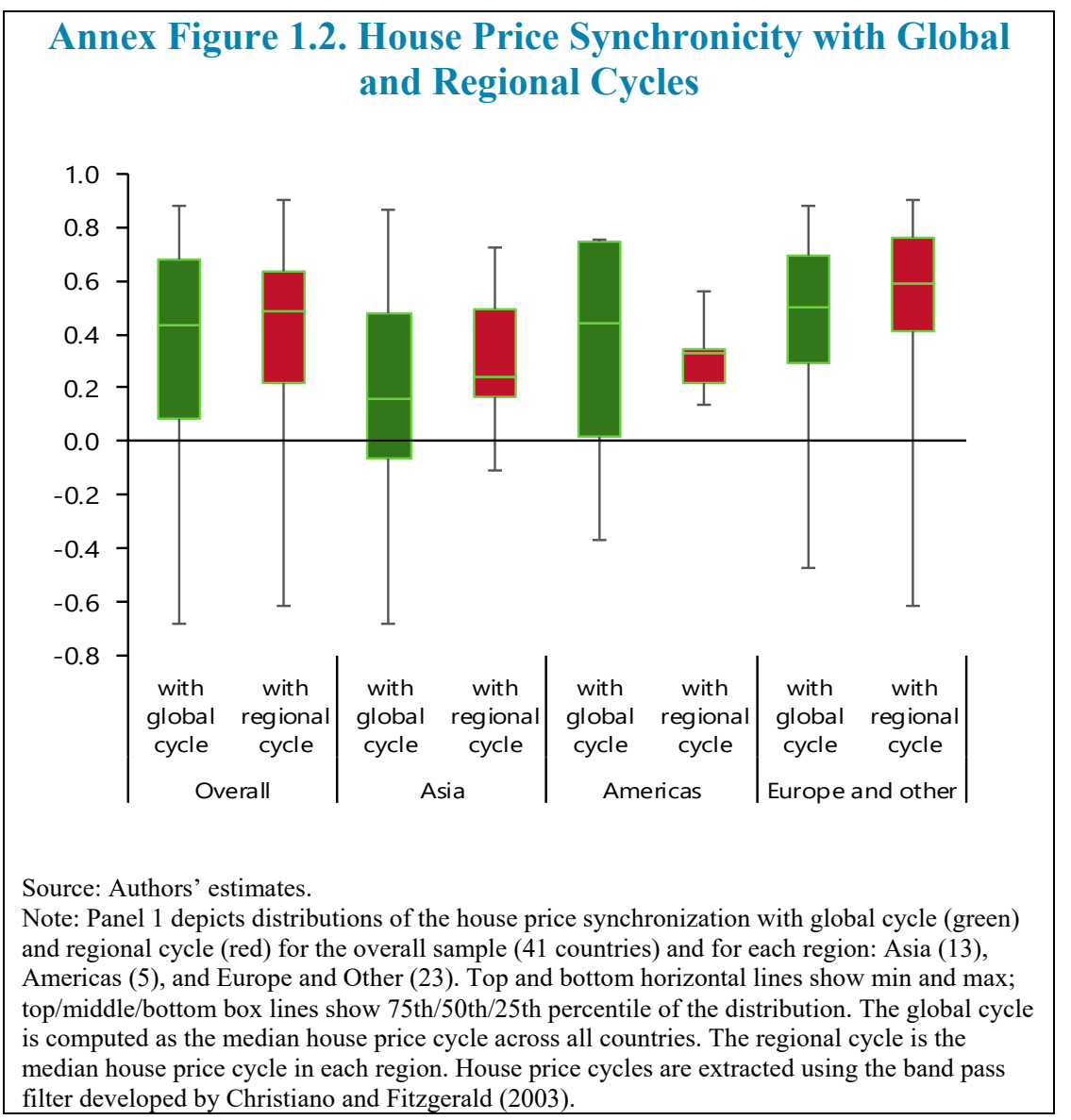

C)International Monetary Fund. Not for Redistribution 


\section{Annex II: Alternative Measures of House Price SynChronicity}

\section{A. Alternative Measure 1: Inverse Absolute Gap Difference (Synch1)}

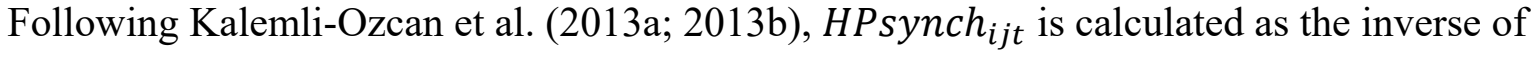
the absolute difference of house price gaps in country $i$ and $j$ at quarter $\mathrm{t}$ as below:

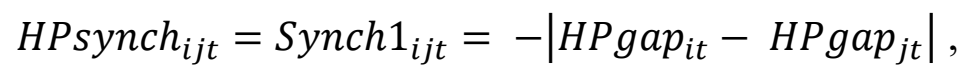

where $H P g a p_{i t}$ and $H P g a p_{j t}$ stand for house price gap of countries $i$ and $j$ respectively at quarter $t .^{24}$

\section{Empirical Strategy}

Similar to equation 4 in Section III of this paper, we estimate the impact of business cycle synchronicity, bilateral financial linkages, and global financial conditions on house price synchronicity using Synch1 measure of house price synchronicity.

$$
\begin{aligned}
{\text { Synch } 1_{i j t}=} & \alpha_{i j}+\beta_{1} B C S_{i j t-1}+\beta_{2} \text { FININT }_{i j t-1}+\beta_{3} G L O B A L_{t-1} \\
& +\beta_{4} I N S T_{i j t-1} \text { x GLOBAL } \\
& \text { GL } \beta_{5} I N S T_{i j t-1}+t r+\varepsilon_{i j t}
\end{aligned}
$$

where Synch $1_{i j t}$ is the synchronicity of house price gaps between country-pair $i$ and $j$ at quarter $t$ measured as presented in equation $\mathrm{A} 2.1 B S C_{i j}$ denotes business cycle synchronicity between country $i$ and $j$ measured as presented in footnote 24 . All other independent variables are as same as in equation 4 introduced in Section III.

\section{Results}

\section{Impact of Bilateral Linkages on House Price Gap Synchronicity}

We estimate the impact of bilateral linkages - business cycle synchronicity (BCS) and bilateral banking integration - on house price synchronicity using Synch $1_{\mathrm{ijt}}$ as an alternative measure of house price and business cycle synchronicity. Given Synch $1_{\mathrm{ijt}}$ is perceived more as of a medium-term measure of synchronicity compared to the instantaneous quasi-correlation, while bilateral banking linkages are measured using stock of assets and liabilities from balance sheet side, we believe Synch $1_{\mathrm{ijt}}$ is a better measure to capture the

\footnotetext{
${ }^{24}$ Business cycle synchronicity (BCS) measure is similar to the house price synchronicity measure presented above.

$$
B C S_{i j t}=-\left|Y_{g a p}-Y_{i t} g a p_{j t}\right| \text {, }
$$

where $\mathrm{Ygap}_{i t}$ and $\mathrm{Ygap}_{j t}$ stand for output gap of country i and $\mathrm{j}$ respectively at quarter $\mathrm{t}$ and measured using Christiano and Fitzgerald band-pass filter (2003), with the maximum length adjusted for business cycles instead of financial cycles.
} 
bilateral linkages that we are analyzing. The global factor that measures global financial conditions (more of a short-term indicator) is included in these specifications only as a control variable and to provide consistency across regression tables.

The results are presented in Table A2.1 below. We find that both BCS and bilateral banking integration have statistically significant positive association with house price synchronicity (columns 1 to 3 ). For comparability of the coefficients, we present the results of the baseline specification (column 4), further standardized in Figure 3. The figure suggests that the impact of both BCS and bilateral bank integration on house price gap synchronicity is comparable in magnitude.

We also find that the impact of bilateral banking integration on house price gap synchronicity is lower among emerging market economy country pairs, compared to that of advanced economy country-pairs (column 5). Moreover, when both countries in the country-pair are de facto more financially open, the positive impact of bilateral banking integration on house price gap synchronicity is muted; this result is statistically significant at a 5 percent confidence interval (column 9). While the impact of

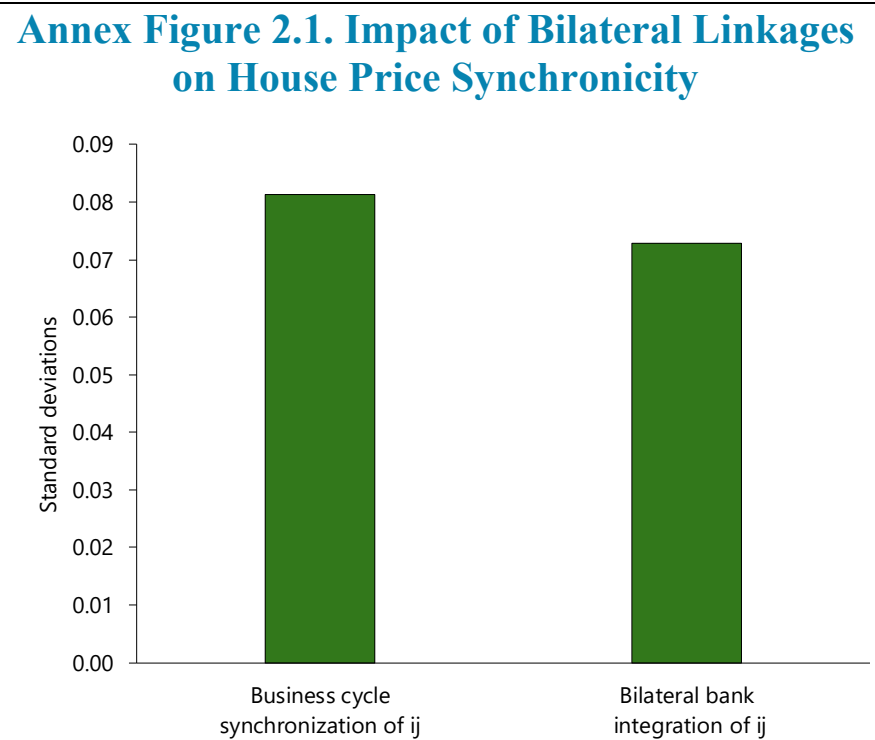

Source: Authors' estimates.

Note: Synchronicity is measured by the Synch1 of gaps measure. Figure shows statistically significant standardized coefficients that are calculated using the coefficients in specification 4 in Table 1 and their respective standard deviations and presented in terms of standard deviations of the dependent variable; this specification also controls for the global financial conditions (proxied through the global liquidity) in addition to country-pair fixed effects, quadratic and linear time trends (standard errors are clustered at multi-way at time, country $i$ and country j). Standard deviation of the country-level dependent variable (synch 1 ) is approximately 0.10 ; standard deviation of the country-level BCS (measured using synch1) is 0.01 ; standard deviation of the bilateral bank integration is $1.04 . \mathrm{i}=$ country 1 and $\mathrm{j}=$ country 2 in the country pair.

banking integration on house price gap synchronicity is positive in our baseline specification in Table A2.1, we fail to find statistically significant impact for the post-GFC period (column $10)$. 


\begin{tabular}{|c|c|c|c|c|c|c|c|c|c|c|}
\hline \multicolumn{11}{|c|}{$\begin{array}{c}\text { Annex Table 2.1. House Price Gap Synchronicity at Country-Level and Bilateral } \\
\text { Linkages }\end{array}$} \\
\hline Dependent Variable: House Price Gap Synchronization of Country Pair i and j (Synch1) & (1) & (2) & (3) & (4) & (5) & (6) & (7) & (8) & (9) & (10) \\
\hline Business Cycle Synchronization of ij & $\begin{array}{l}0.766^{* * *} \\
(0.254)\end{array}$ & $\begin{array}{l}0.675^{* *} \\
(0.293)\end{array}$ & $\begin{array}{c}0.733^{\star \star \star *} \\
(0.243)\end{array}$ & $\begin{array}{l}0.657^{\star \star} \\
(0.254)\end{array}$ & $\begin{array}{l}0.658^{* *} \\
(0.253)\end{array}$ & $\begin{array}{l}0.746^{\star * *} \\
(0.262)\end{array}$ & $\begin{array}{c}0.725^{* * *} \\
0.261 *\end{array}$ & $\begin{array}{c}0.725^{\star * *} \\
0.262)\end{array}$ & $0.675^{\star \star}$ & $0.700^{\star *}$ \\
\hline Bilateral Bank Integration of ij & & & $\begin{array}{l}0.006^{*} \\
(0.003)\end{array}$ & $\begin{array}{l}0.0074) \\
0.003)\end{array}$ & $\begin{array}{c}0.012 \\
0.007)\end{array}$ & $\begin{array}{l}0.009^{*} \\
(0.004)\end{array}$ & $\begin{array}{l}0.007^{\text {t* }} \\
(0.003)\end{array}$ & $\begin{array}{l}0.007^{*} \\
(0.004)\end{array}$ & $\begin{array}{l}0.007 * \\
0.003)\end{array}$ & $\begin{array}{l}0.004 \\
0.005\end{array}$ \\
\hline Global Factor (global liquidity) & & & & $\begin{array}{l}0.003) \\
-0.001 \\
(0.001)\end{array}$ & $\begin{array}{l}-0.001 \\
-0.001)\end{array}$ & $\begin{array}{l}-0.004) \\
-0.001 \\
(0.001)\end{array}$ & $\begin{array}{l}-0.003) \\
-0.001 \\
(0.001)\end{array}$ & $\begin{array}{l}-0.004) \\
-0.001 \\
(0.001)\end{array}$ & $\begin{array}{l}-0.001 \\
(0.001)\end{array}$ & $\begin{array}{l}0.001 \\
0.001 \\
(0.001)\end{array}$ \\
\hline $\begin{array}{l}\text { Bilateral Bank Integration Interacted with: } \\
\text { x EMEs-EMEs Dummy }\end{array}$ & & & & & $\begin{array}{c}-0.016^{*} \\
(0.009) \\
-0.009 \\
(0.010)\end{array}$ & & & & & \\
\hline x High Capital Account Openness with the World & & & & & & $\begin{array}{l}-0.005 \\
(0.003)\end{array}$ & & & & \\
\hline x High Exchange Rate Regime (ij) (15 categories; high = more flexible) & & & & & & & $\begin{array}{l}-0.005 \\
(0.004)\end{array}$ & & & \\
\hline x High Exchange Rate Regime (ij) 6 categories; high = more flexible) & & & & & & & & $\begin{array}{l}-0.001 \\
(0.004)\end{array}$ & & \\
\hline $\mathrm{x}$ High Financial Openness with the World (ij) & & & & & & & & \multicolumn{3}{|c|}{$\begin{array}{c}-0.019^{* k \star} \\
(0.004)\end{array}$} \\
\hline \multicolumn{11}{|l|}{ GFC Period Dummy Interacted with: } \\
\hline$x$ Business Cycle Synchronization of $\mathrm{ij}$ & & & & & & & & & & $\begin{array}{l}-0.080 \\
(0.516)\end{array}$ \\
\hline x Bilateral Bank Integration of ij & & & & & & & & & & $\begin{array}{l}0.008^{* *} \\
(0.004)\end{array}$ \\
\hline x Global Factor & & & & & & & & & & $\begin{array}{l}0.001 \\
(0.001)\end{array}$ \\
\hline \multicolumn{11}{|l|}{ Post-GFC Period Dummy Interacted with: } \\
\hline$x$ Business Cycle Synchronization of ij & & & & & & & & & & $\begin{array}{l}0.380 \\
(0.456)\end{array}$ \\
\hline$x$ Bilateral Bank Integration of $\mathrm{ij}$ & & & & & & & & & & $\begin{array}{l}0.007 \\
(0.005)\end{array}$ \\
\hline $\mathrm{x}$ Global Factor & & & & & & & & & & $\begin{array}{l}0.004 \\
(0.003)\end{array}$ \\
\hline GFC Dummy & & & & & & & & & & $\begin{array}{c}0.048^{*+k} \\
(0.011)\end{array}$ \\
\hline Post-GFC Dummy & & & & & & & & & & $\begin{array}{l}0.042^{* * *} \\
(0.009)\end{array}$ \\
\hline Observations & 65,450 & 65,343 & 49,384 & 49,384 & 49,384 & 43,871 & 46,708 & 46,708 & 47,353 & 49,384 \\
\hline R-Squared & 0.353 & 0.498 & 0.386 & 0.356 & 0.356 & 0.361 & 0.356 & 0.356 & 0.360 & 0.360 \\
\hline Multiway Clustering & Yes & Yes & Yes & Yes & Yes & Yes & Yes & Yes & Yes & Two-way \\
\hline Group & All & All & All & All & All & All & All & All & All & All \\
\hline Time FE and Country-Pair FE & Yes & & Yes & & & & & & & \\
\hline Time FE, Country-Pair FE, and country'time FE & & Yes & & & & & & & & \\
\hline $\begin{array}{l}\text { Quadratic Trend and Country-Pair FE } \\
\text { Country-Pair FE }\end{array}$ & & & & Yes & Yes & Yes & Yes & Yes & Yes & Yes \\
\hline $\begin{array}{l}\text { Source: Authors' estimates. } \\
\text { Note: GFC Dummy }=\text { a dummy variable that equals } 1 \text { during } 2008-09 \\
\text { equals } 1 \text { curing } 2010-16 \text {, and zero otherwise. All regressors are lagge } \\
\text { specifications } 5 \text { through } 9 \text {, but are not shown above (specifically, dum } \\
\text { openness, high exchange rate regime, high financial openness are incl } \\
\text { variable that equals } 1 \text { when both countries are in the top fifth of the in } \\
\text { clustered (at country } \mathrm{i} \text {, country } \mathrm{j} \text {, and date), with the exception of regre } \\
\text { j). AEs }=\text { advanced economies; EMEs }=\text { emerging market economies; } \\
* * * p<0.01 ; * * p<0.05 ; * p<0.1 \text {. }\end{array}$ & $\begin{array}{l}\text { and zerc } \\
\text { by one } \\
\text { ly varial } \\
\text { led in sp } \\
\text { itutiona } \\
\text { sion (10 } \\
\mathrm{E}=\text { fixe }\end{array}$ & $\begin{array}{l}\text { o other } \\
\text { quarter. } \\
\text { bles for } \\
\text { pecifica } \\
1 \text { chara } \\
\text { o), in w } \\
\text { ed effec }\end{array}$ & $\begin{array}{l}\text { wise. P } \\
\text { Institu } \\
\text { r EMEs } \\
\text { ations } 5 \\
\text { cteristic } \\
\text { hich er } \\
\text { cts; GFC }\end{array}$ & $\begin{array}{l}\text { ost-GF( } \\
\text { ttional } \\
\text {-EMEs } \\
\text { throug } \\
\text { c. Stand } \\
\text { rors are } \\
C=\text { glo }\end{array}$ & $\begin{array}{l}\text { C Dum } \\
\text { charact } \\
\text { EMEs } \\
\text { h 9, bu } \\
\text { lard err } \\
\text { two-w } \\
\text { bal fina }\end{array}$ & $\begin{array}{l}\text { Imy = a } \\
\text { teristics } \\
\text { s-AEs, } \\
\text { it not sl } \\
\text { rors (in } \\
\text { vay clu } \\
\text { ancial }\end{array}$ & $\begin{array}{l}\text { dumm } \\
\text { dumm } \\
\text { high ce } \\
\text { hown). } \\
\text { parentl } \\
\text { stered ( } \\
\text { crisis. }\end{array}$ & $\begin{array}{l}\text { y varia } \\
\text { ies are } \\
\text { apital a } \\
\text { High = } \\
\text { heses) } \\
\text { at coun }\end{array}$ & $\begin{array}{l}\text { ble that } \\
\text { include } \\
\text { ccount } \\
\text { a dum } \\
\text { are thre } \\
\text { try i, ce }\end{array}$ & $\begin{array}{l}\text { ted in } \\
\text { lmy } \\
\text { ee-way } \\
\text { country }\end{array}$ \\
\hline
\end{tabular}

\section{CInternational Monetary Fund. Not for Redistribution}




\section{B. Alternative Measure 2: Pearson Correlations}

In a separate exercise, regressions were run using a panel of three non-overlapping seven-year periods (in other words, three non-overlapping 28 quarter periods), in which the house price and business cycle synchronicity is captured by the bilateral Pearson correlation coefficients for the period. All other explanatory variables are the average values for the period. Further robustness checks in this exercise were employed by collapsing the other explanatory variables using the last value of the previous period instead. The interaction term of the global factor and foreign exchange regime continues to be statistically significant, in addition to the global factor itself (Table A2.2).

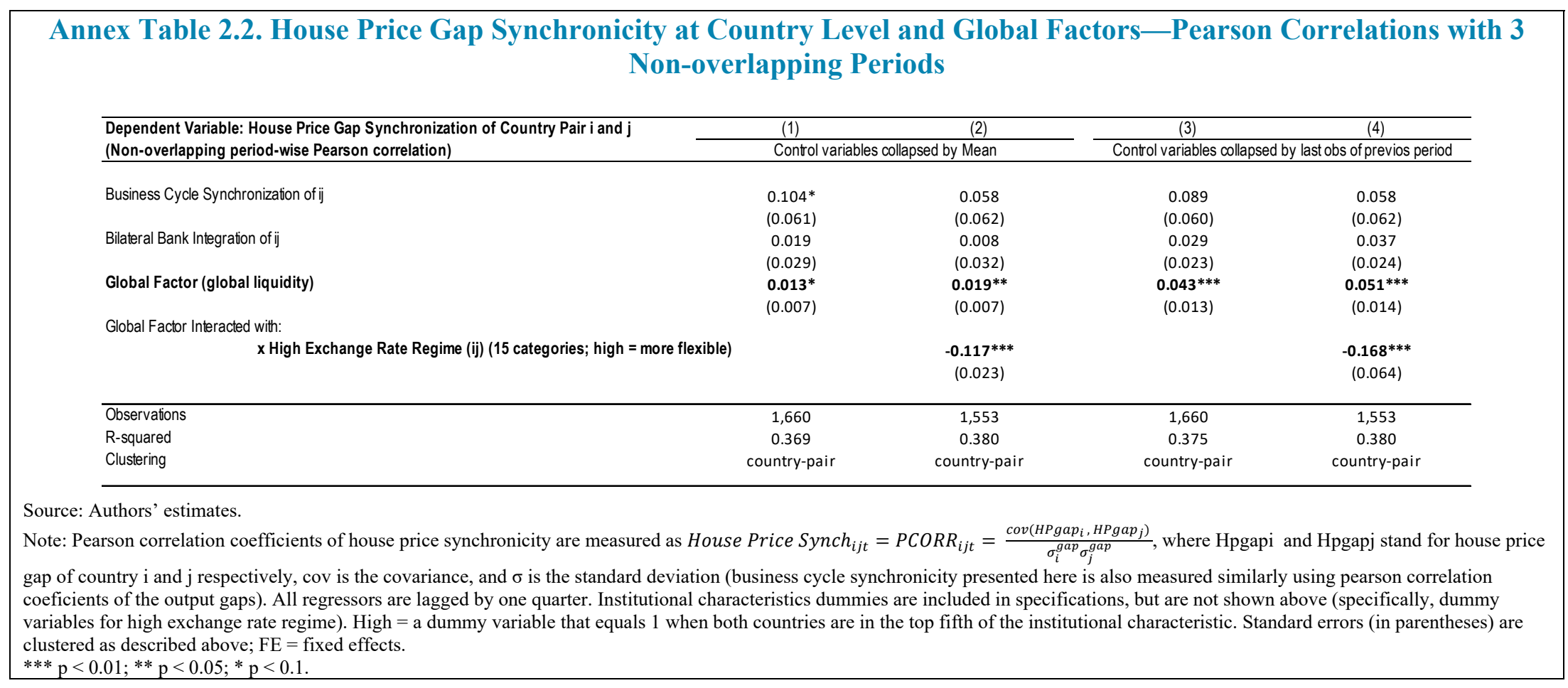




\section{Alternative Measure 3: Synchronicity with Longer time series}

The relationship between house price gap synchronicity and BCS is found to be positive and statistically significant when Jordà-Schularick-Taylor (2017) dataset is considered. This analysis contains annual observations from 1870 to 2013 for 17 advanced economies is used (Table A2.3). Additional analysis was limited by data availability.

\begin{tabular}{|c|c|c|c|c|c|c|c|c|}
\hline $\begin{array}{r}\text { Annex Table 2.3. House Price Gap Synchro } \\
\text { Jordà }\end{array}$ & $\begin{array}{l}\text { ountry I } \\
\text { k-Taylor }\end{array}$ & Datase & $\begin{array}{l}\text { d Busine } \\
\text { t-1870 }\end{array}$ & $\begin{array}{l}\text { is Cycl } \\
2013\end{array}$ & nchron & city-E & timatios & s using \\
\hline \multirow{2}{*}{ Dependent Variable: House Price Gap Synchronization of Country Pair i and j } & $(1)$ & $(2)$ & $(3)$ & $(4)$ & $(5)$ & $(6)$ & $(7)$ & $(8)$ \\
\hline & \multicolumn{4}{|c|}{ Synch 1} & \multicolumn{4}{|c|}{ Quasi-correlation } \\
\hline Business Cycle Synchronization of ij & $\begin{array}{c}0.902 * * \\
(0.385)\end{array}$ & $\begin{array}{c}0.902 * * \\
(0.311)\end{array}$ & $\begin{array}{c}\mathbf{0 . 9 0 2} * * * \\
(0.153)\end{array}$ & $\begin{array}{c}0.902 * * * \\
(0.089)\end{array}$ & $\begin{array}{c}\mathbf{0 . 0 4 2} \\
(0.032)\end{array}$ & $\begin{array}{l}0.042^{*} \\
(0.024)\end{array}$ & $\begin{array}{c}\mathbf{0 . 0 4 2} * * * \\
(0.015)\end{array}$ & $\begin{array}{c}\mathbf{0 . 0 4 2 * * *} \\
(0.008)\end{array}$ \\
\hline Observations & 9,818 & 9,818 & 9,818 & 9,818 & 9,818 & 9,818 & 9,818 & 9,818 \\
\hline R-squared & 0.143 & 0.143 & 0.143 & 0.143 & 0.071 & 0.071 & 0.071 & 0.071 \\
\hline Clustering & Multi-way & Two-way & VCE robust & No & Multi-way & Two-way & VCE robust & No \\
\hline Quadratic Trend and Country-Pair FE & Yes & Yes & Yes & Yes & Yes & Yes & Yes & Yes \\
\hline
\end{tabular}




\section{AnNeX III: Methodology-House Price Interconnectedness AnAlysis}

Following the methodology proposed by Diebold and Yilmaz (2014), we measure house price interconnectedness based on a large-scale vector autoregressive (VAR) model. The econometric framework is estimated separately using quarter-on-quarter house price growth rates at the country- and city-level, while controlling for global financial conditions. Within the VAR model, the interconnectedness is defined as the fraction of H-quarter-ahead forecast error variance of country/city j's house price growth that can be accounted for by country/city i's house prices growth dynamics.

Quarterly house price growth rates are computed using seasonally adjusted real house prices either at country-level or at city-level. Global financial conditions in this analysis are proxied by the U.S. Financial Conditions Index (FCI) constructed in line with IMF 2017. ${ }^{25}$ The estimation period for the country-level analysis spans from 1990:Q1 to 2016:Q4, while for city-level interconnectedness analysis, owing to data limitations, is estimated for a period spanning from 2004:Q1 to 2017:Q2.

The number of countries and cities in our samples - that enters as the set of variables in the VAR setting - is large $(n=30)$. Following Demirer et al. (2018), Song and Bickel (2011), the VAR is estimated using machine learning techniques such as lasso and elastic net which allow for the estimation of large-scale VARs.

The baseline house price interconnectedness specification we estimated can be described as follows:

$$
Y_{t}=\alpha+\sum_{\substack{i=1 \\ u_{t} \sim \operatorname{iid}\left(o, \Sigma_{u}\right)}}^{p} \gamma_{i} Y_{t-i}+\sum_{j=0}^{p} \beta_{j} X_{t-j}+u_{t}
$$

, where Y stands for quarterly house price growth variavles for 32 countries or 30 major cities that enter as endogenous variables in the VAR setting. U.S. FCI is used to contol for global financial conditions, where robustness checks were performed with variables mentioned in the footnote 25 .

\footnotetext{
${ }^{25}$ Robustness checks were performed using the global FCI and the VIX index, and results are found to be very similar.
} 


\section{Annex IV: Impact of Macroprudential Measures on House Price Synchronicity-Regression Results}

\begin{tabular}{|c|c|c|c|c|c|c|c|c|c|c|c|c|c|c|c|c|c|c|}
\hline \multicolumn{19}{|c|}{ Annex Table 4.1. Unconditional Estimation Sample } \\
\hline \multirow{2}{*}{$\begin{array}{l}\text { Dependent variable: house price gap } \\
\text { synchronicity (quasi-correlation) with: }\end{array}$} & (1) & (2) & (3) & (4) & (5) & (6) & (7) & (8) & (9) & (10) & (11) & (12) & (13) & (14) & (15) & (16) & (17) & (18) \\
\hline & Region & World & Region & World & Region & world & Region & World & Region & World & Region & World & Region & World & Region & World & Region & World \\
\hline \multirow[t]{2}{*}{ Global factor (FCI) } & -0.051 & $-0.084^{* *}$ & -0.050 & $-0.083^{* *}$ & -0.053 & $-0.086^{* *}$ & -0.052 & $-0.085 * *$ & -0.052 & $-0.084^{* *}$ & -0.052 & $-0.085^{* *}$ & -0.049 & $-0.083^{* *}$ & -0.058 & $-0.089^{* *}$ & -0.051 & $-0.084^{* *}$ \\
\hline & $\begin{array}{c}(0.037) \\
0.028\end{array}$ & $(0.040)$ & $\begin{array}{c}(0.037) \\
0.030\end{array}$ & & $\begin{array}{c}(0.037) \\
0.029\end{array}$ & & $\begin{array}{c}(0.037) \\
0.028\end{array}$ & $(0.040)$ & $\begin{array}{c}(0.037) \\
0.029\end{array}$ & & $\begin{array}{c}(0.037) \\
0.029\end{array}$ & $(0.040)$ & $\begin{array}{c}(0.037) \\
0.030\end{array}$ & $(0.040)$ & $\begin{array}{c}(0.037) \\
0.027\end{array}$ & & $\begin{array}{c}(0.037) \\
0.029\end{array}$ & \\
\hline Business cycle synchronicity with the region & $(0.020)$ & & (0.019) & & (0.019) & & (0.019) & & $(0.020)$ & & $(0.019)$ & & $(0.020)$ & & $(0.019)$ & & $(0.019)$ & \\
\hline \multirow[t]{2}{*}{ Bank integration with the region } & 0.013 & & 0.012 & & 0.013 & & 0.013 & & 0.013 & & 0.012 & & 0.012 & & 0.013 & & 0.013 & \\
\hline & $(0.013)$ & & $(0.013)$ & & $(0.013)$ & & $(0.013)$ & & $(0.013)$ & & $(0.013)$ & & $(0.013)$ & & $(0.013)$ & & $(0.013)$ & \\
\hline \multirow[t]{2}{*}{ Business cycle synchronicity with the world } & & $0.041^{* *}$ & & $0.043^{* *}$ & & $0.042^{* *}$ & & $0.042^{* *}$ & & $0.042^{* *}$ & & $0.043^{* *}$ & & $0.043^{* *}$ & & $0.041^{* *}$ & & $0.043^{* *}$ \\
\hline & & $(0.020)$ & & $(0.019)$ & & $(0.019)$ & & $(0.019)$ & & $(0.020)$ & & $(0.019)$ & & $(0.019)$ & & $(0.019)$ & & $(0.019)$ \\
\hline \multirow[t]{2}{*}{ Bank integration with the world } & & 0.027 & & 0.026 & & 0.027 & & 0.027 & & 0.027 & & 0.027 & & 0.027 & & 0.028 & & 0.027 \\
\hline & & $(0.020)$ & & $(0.020)$ & & $(0.020)$ & & $(0.020)$ & & $(0.020)$ & & $(0.020)$ & & $(0.020)$ & & $(0.020)$ & & $(0.020)$ \\
\hline \multicolumn{19}{|l|}{ Macroprudential measures } \\
\hline LTV & $\begin{array}{c}-0.097^{* *} \\
(0.045)\end{array}$ & $\begin{array}{c}-0.128^{* * *} \\
(0.040)\end{array}$ & & & & & & & & & & & & & & & & \\
\hline Fiscal-based measures & & & $\begin{array}{c}-0.132 \\
(0.144)\end{array}$ & $\begin{array}{l}-0.122^{*} \\
(0.067)\end{array}$ & & & & & & & & & & & & & & \\
\hline All measures & & & & & $\begin{array}{l}-0.027 \\
(0.019)\end{array}$ & $\begin{array}{c}-0.032^{* *} \\
(0.016)\end{array}$ & & & & & & & & & & & & \\
\hline All loan-targeted & & & & & & & $\begin{array}{c}-0.064^{* * *} \\
(0.022)\end{array}$ & $\begin{array}{c}-0.064^{* *} \\
(0.025)\end{array}$ & & & & & & & & & & \\
\hline Demand side & & & & & & & & & $\begin{array}{c}-0.077^{* *} \\
(0.033)\end{array}$ & $\begin{array}{l}-0.059 \\
(0.038)\end{array}$ & & & & & & & & \\
\hline Supply side: all & & & & & & & & & & & $\begin{array}{c}-0.020 \\
(0.029)\end{array}$ & $\begin{array}{l}-0.026 \\
(0.024)\end{array}$ & & & & & & \\
\hline Supply side: general & & & & & & & & & & & & & $\begin{array}{c}0.042 \\
(0.030)\end{array}$ & $\begin{array}{c}0.012 \\
(0.031)\end{array}$ & & & & \\
\hline Supply side: capital & & & & & & & & & & & & & & & $\begin{array}{c}-0.230^{* * *} \\
(0.074)\end{array}$ & $\begin{array}{l}-0.174^{* *} \\
(0.071)\end{array}$ & & \\
\hline Supply side: Ioans & & & & & & & & & & & & & & & & & $\begin{array}{c}-0.092^{* *} \\
(0.044)\end{array}$ & $\begin{array}{c}-0.123^{* *} \\
(0.055)\end{array}$ \\
\hline Observations & 3,520 & 3,520 & 3,520 & 3,520 & 3,520 & 3,520 & 3,520 & 3,520 & 3,520 & 3,520 & 3,520 & 3,520 & 3,520 & 3,520 & 3,520 & 3,520 & 3,520 & 3,520 \\
\hline R-squared & 0.008 & 0.017 & 0.007 & 0.015 & 0.008 & 0.017 & 0.009 & 0.017 & 0.008 & 0.016 & 0.007 & 0.015 & 0.008 & 0.015 & 0.015 & 0.020 & 0.008 & 0.017 \\
\hline $\begin{array}{l}\text { Source: Authors' estimates. } \\
\text { Note: All regressors are lagged by one } \\
\text { (capital) consists of capital requiremer } \\
\text { requirements, and limits on foreign ex } \\
\text { (loans). Fiscal-based measures include } \\
\text { parentheses. } \\
* * * \mathrm{p}<0.01 ; * * \mathrm{p}<0.05 ; * \mathrm{p}<0.1 \text {. }\end{array}$ & $\begin{array}{l}\text { arter. Su } \\
\text { conserv } \\
\text { nge posi } \\
\text { xes such }\end{array}$ & $\begin{array}{l}\text { Ipply sid } \\
\text { ation bu } \\
\text { itions. D } \\
\text { as ad va }\end{array}$ & $\begin{array}{l}\text { (loans } \\
\text { fers, th } \\
\text { emand- } \\
\text { lorem, }\end{array}$ & $\begin{array}{l}\text { everag } \\
\text { le inclu } \\
\text { ler's at }\end{array}$ & lim & $\begin{array}{l}\text { to de } \\
\text { stam }\end{array}$ & $\begin{array}{l}\text { t grow } \\
\text { untercy } \\
\text { service } \\
\text { luty, o }\end{array}$ & $\begin{array}{l}\text { loan } \\
\text { ical ce } \\
\text { o-ince } \\
\text { ther to }\end{array}$ & $\begin{array}{l}\text { ss prov } \\
\text { tal buf } \\
\text { e and } \\
\text { s. All }\end{array}$ & $\begin{array}{l}\text { ns, lo } \\
\text { Supp } \\
V \text { ratio } \\
\text { ressior }\end{array}$ & $\begin{array}{l}\text { All lo } \\
\text { inclu }\end{array}$ & $\begin{array}{l}\text { eral) } \\
\text { target } \\
\text { countr }\end{array}$ & meas & $\begin{array}{l}\text { foreig } \\
\text { reserve } \\
\text { s inclu } \\
\text { cts. Rc }\end{array}$ & $\begin{array}{l}\text { currer } \\
\text { equire } \\
\text { e dem } \\
\text { ust sta }\end{array}$ & $\begin{array}{l}\text { loan } \\
\text { ents, } 1 \\
\text { side } \\
\text { ard e }\end{array}$ & $\begin{array}{l}\text { upply } \\
\text { idity } \\
\text { d supp } \\
\text { s are }\end{array}$ & $\begin{array}{l}\text { de } \\
\text { side } \\
\text { sented ir }\end{array}$ \\
\hline
\end{tabular}




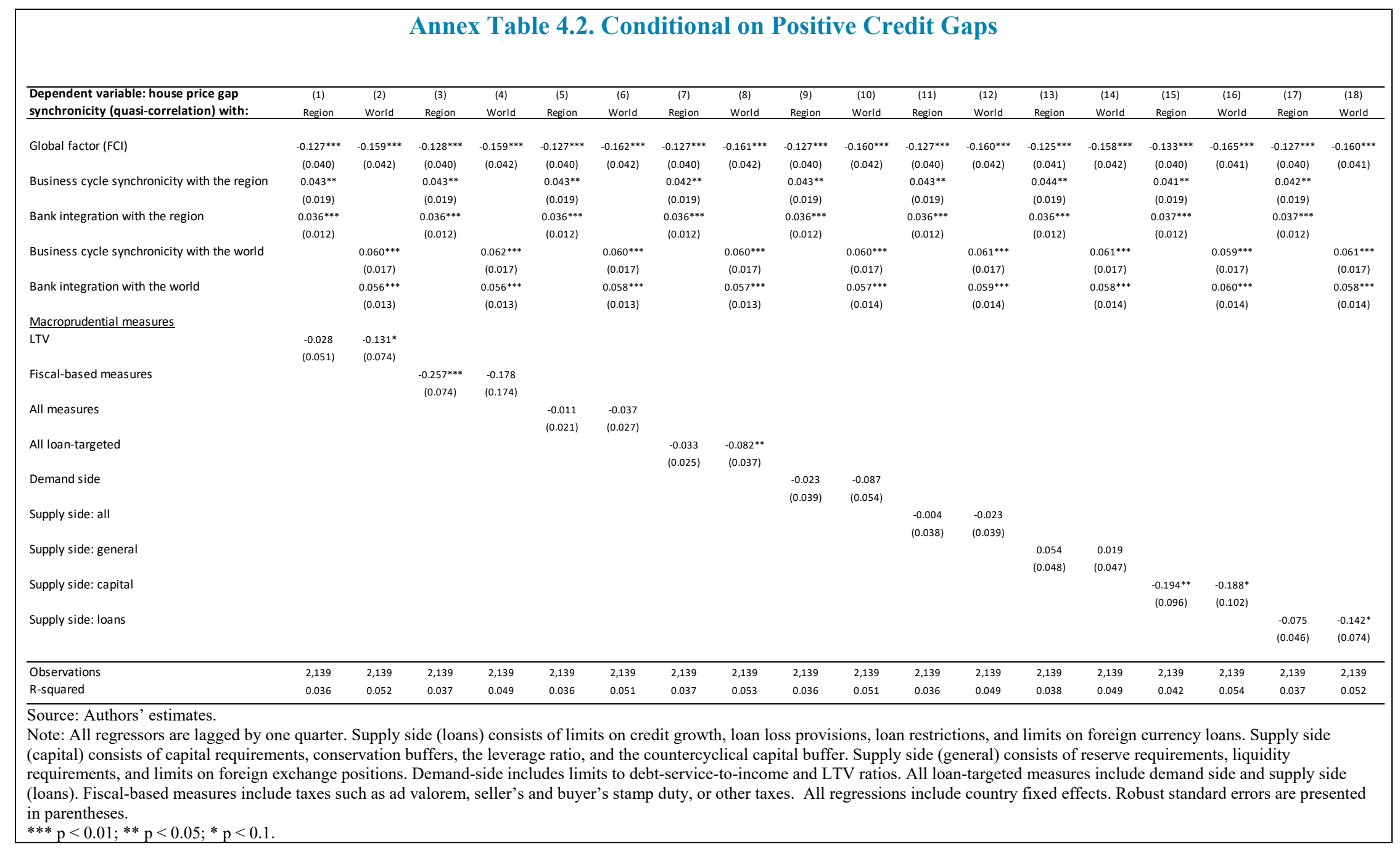

